\title{
Consulting and Capital Experiments with Microenterprise Tailors in Ghana ${ }^{1}$
}

\section{Dean Karlan}

Ryan Knight

Christopher Udry

\section{October 2014}

\begin{abstract}
We conducted a randomized trial in urban Ghana in which tailoring microenterprises received advice from an international consulting firm, cash, both, or neither. We designed the study with a hypothesis that large infusions of financial and managerial capital could be transformative. We find that all three treatments led to their immediate intended effects: changed business practices and increased investment. However, no treatment led to higher profits on average, and certainly not to the large effects hypothesized. In fact, each treatment at some point led to lower profits. Then, in the long run, we find that the microentrepreneurs in either consulting treatment group reverted back to their prior business practices, and that microentrepreneurs in the cash treatment group reverted back to their prior scale of operations.
\end{abstract}

JEL Codes: D21, D24, D83, D92, L20, M13, O12

Keywords: entrepreneurship; credit constraints; business training; consulting; managerial capital

\footnotetext{
${ }^{1}$ Contact information: dean.karlan@yale.edu (Yale University, Innovations for Poverty Action, M.I.T. Jameel Poverty Action Lab, and NBER); ryan.knight@yale.edu (Yale University and Innovations for Poverty Action), and christopher.udry@yale.edu (Yale University). The authors thank USAID-BASIS and the Bill and Melinda Gates Foundation for funding, Matt Hoover for project management and research assistance, the field staff at Innovations for Poverty Action (IPA) for survey and project management, and the IPA Ghana country directors, Justin Oliver, Kelly Bidwell and Jessica Kiessel. The authors thank the Ernst \& Young Ghana office for their collaboration. Institutional Review Board approval received from both Yale University and Innovations for Poverty Action. The authors retained full intellectual freedom to report and interpret the results throughout the study. All opinions herein are our own and not those of any of the donors or partners.
} 


\section{Introduction}

We test whether providing urban microenterprises with capital, consulting services or both can help relax constraints and facilitate growth for microentrepreneurial tailors. The interventions were not intended to be scalable: the capital was provided as grants, not loans, and the consulting services were costly relative to the firm size. Rather, we ask whether the transformation from microenterprise to small or medium business is possible, even with a concerted "big push" effort, given the mixed evidence on the impacts of credit and training programs ${ }^{2}$.

We conducted a randomized trial in Accra, Ghana with 160 microenterprise urban tailors from 2008-2011. A capital treatment group of 36 tailors received grants of 200 cedis (about US \$133), doubling their average working capital. This is a similar size grant to those provided in other grant experiment studies (Beaman et al. 2014; Berge, Bjorvatn, and Tungooden 2014; de Mel, McKenzie, and Woodruff 2008; Fafchamps et al. 2014; Karlan et al. 2013). A consulting treatment group of 41 tailors received one year of management consulting services from Ernst \& Young ("E\&Y"), a major international consulting firm. Four talented and creative professional business consultants, who know the local business environment, were assigned to these 41 firms for one year to provide advisory services. A third treatment group of 36 tailors received both the cash grant and the management consulting. The control group contained 45 tailors.

The consulting treatment was thus interactive and tailored to the individual entrepreneur; this was one-on-one consulting, whereas most entrepreneurship training interventions in the literature are more generic training, often to a group (e.g., see Berge, Bjorvatn, and Tungooden 2014; Bruhn and Zia 2011; Calderon, Cunha, and de Giorgi 2013; Drexler, Fischer, and Schoar 2011; Giné and Mansuri 2011; Karlan

\footnotetext{
${ }^{2}$ The impact of microcredit results are fairly consistent in showing modest but not transformative results (Angelucci, Karlan, and Zinman 2015; Attanasio et al. 2015; Augsburg et al. 2015; Banerjee et al. 2015; Crépon et al. 2015; Karlan and Zinman 2010; Karlan and Zinman 2011; Tarozzi, Desai, and Johnson 2015; and for a summary, see Banerjee, Karlan, and Zinman 2014). The impact of entrepreneurial training programs are more mixed (e.g., see Berge, Bjorvatn, and Tungooden 2014; Bloom et al. 2012; Bruhn, Karlan, and Schoar 2013; Bruhn and Zia 2011; Calderon, Cunha, and de Giorgi 2013; Drexler, Fischer, and Schoar 2011; Giné and Mansuri 2011; Karlan and Valdivia 2011; Valdivia 2014).
} 
and Valdivia 2011; Valdivia 2014). Two studies, however, are similar to ours in providing one-on-one consulting, rather than training: Bruhn, Karlan and Schoar in Mexico (2013) and Bloom et al in India (2012). Both find strong positive results, but are with much larger firms than our experiment.

The context and heterogeneity of experiences of tailors can be illustrated by the stories of two of the respondents:

"Jess" was 26 years old, had attended vocational school to be a seamstress, and financed her startup capital herself. She was single with no children and cared for a sick mother. She had a bank account but had never applied for a loan from a bank or microfinance institution. She sewed out of a wooden kiosk, and the fair value of her total capital was 765 cedis $(\$ 510)$. She carried all of her materials back and forth from her home to the shop every day because she was worried they would be stolen from her shop, which lacked a secure padlock, and had been broken into before. A strong padlock would cost about 25 cedis $(\$ 17)$, but she had drained all of her working capital from the business caring for her mother. She had recently stopped sewing for an extended period of time because caring for her mother was time consuming, and when she returned she found her primary clients had found another seamstress. She wanted to rebuild her customer base, but did no marketing and had no advertising signs. She spoke softly, did not make eye contact and was shy with new people, but spoke briskly to well-known clients.

Across town, "Sarah" was 28 years old, had attended a polytechnic school for fashion, and had inherited her business four years before the baseline. She had two bank accounts, one for business and one personal, and unlike Jess had previously received a loan. The fair value of her capital was 2730 cedis (\$1840). Sarah had two good sewing machines and a couple of special purpose machines, which she kept in her concrete shop. The quality of her sewing was good, and she was already keeping transaction records at the baseline. However, her shop was on an out-of-the-way street in a tough neighborhood, so she slept on the floor of her shop to protect her machines. She identified a new site on a main road that she wanted to move to, but she was having trouble saving up enough money. She had a natural ease with 
customers, but her relationships with her employee and apprentice were tense. The consultants judged Sarah to have great potential and they wanted to help her start marketing, but were concerned about her location and ability to effectively manage her employees as she grew.

Both of these women appeared to face capital constraints. Jess had liquidated her business money for a personal emergency, and could not afford a small amount for a padlock to protect her investment. Sarah believed that a new location would be more profitable, but she could not save enough to move.

Both also faced managerial challenges. Jess needed to work on her customer service and needed to develop a plan to reconnect with her old clients and attract new clients. Sarah needed to learn to be a more effective manager and begin doing marketing.

Jess and Sarah both received the double treatment of the mentoring and the capital grants. At the end of the study, Jess was mourning her lost mother and hardly working. She had not reclaimed her old clients or launched any new marketing campaigns. She tried out record keeping for a time, but stopped keeping any records. She invested the capital grant in fabrics that she hoped to sell from her kiosk, but still had no padlock and was still carrying her material back and forth from home every day. The consultant worked on a plan to put a little money away every day for the padlock, but she was not saving.

Sarah, on the other hand, stood out for how well she adopted the consulting. With her consultant's guidance, she began "sew and sell" - sewing products with no specific customer in mind and selling them from her shop. She saved the capital grant for improvements to her new shop and expanded her record keeping. She added a small dressing room area to her shop and gave purified water satchels and candies out to clients. She designed a label with her phone number on it that she started affixing to all of the items she sewed. She successfully helped an apprentice start her own business, found a new apprentice to replace her, and hired a second employee.

Sarah's experience shows that there is much that a microentrepreneur can do to expand her business and improve her business practices. Sarah's efforts increased her profits from 90 cedis in 
December 2008 to 333 cedis in December 2010, more than twice the average control group increase of 109 cedis. Jess, by contrast, saw her profits increase from 30 cedis in December 2008 to 80 cedis in December 2010, less than half the average control group increase. Jess' contrary experience shows that this is not always easy, and not everyone is capable of making large changes in their business model.

We found that, on average, the experience of the tailors was more similar to that of Jess than to that of Sarah. The entrepreneurs invested the cash and took the consultants' advice, but no treatment led to higher profits on average, and in fact each treatment led to lower profits at some point after adoption. Then, in the long run, the microentrepreneurs in the cash only treatment group reverted back to their prior scale of operations and the microentrepreneurs in either consulting treatment group reverted back to their prior business practices, nor was there meaningful long run change in firm size.

This sequence of events is consistent with the idea that entrepreneurial talent is heterogeneous and not perfectly observed, even by the entrepreneur herself. In order to understand the optimal scale and organization of their business, entrepreneurs must experiment. This experimentation can take the form of using recommended but difficult to implement managerial strategies, adopting previously unknown business practices, or investing in additional equipment or inputs to expand the size of the business. However, financial and managerial capital market imperfections impede this experimentation. Relaxing these constraints encourages some entrepreneurs to experiment, but such experimentation will not necessarily lead to success and in fact on average will not succeed. Online Appendix A contains a model, originally developed in Karlan, Knight and Udry (2012), that formalizes this reasoning. Our results are consistent, therefore, with rational experimentation by entrepreneurs unsure about their ability to manage a larger, more sophisticated business. These results were not, however, what was expected in the design of the study. We discuss in the conclusion how laboratory experiments in the field would have helped validate such a story, similar to the approach taken in Berge, Bjorvatn and Tungooden (2014). 


\section{Sample Frame, Interventions and Data}

\section{a) Sample}

We chose to work with microenterprises in a single industry because it allowed the consultants to develop expertise in that sector and allowed us to focus on industry-specific survey questions. We looked for an industry with continuous variation in firm size, including both microenterprises and large firms (making growth plausible), without concentration in a particular part of Accra (minimizing possible spillovers to control groups), and with large enough potential sample size to conduct this study. The tailor industry fits these requirements: tailors are easy to find throughout the city, one-person tailoring shops are common, but firms with more employees also exist. Naturally, this focus on tailoring limits the ability to compare results to studies with a wide variety of industries, and other studies that we know of do not have enough tailors to compare our results to just the tailors in those studies.

The 160 study participants were randomly selected from an enumeration in eight neighborhoods in/around Accra of all tailors and seamstresses with five or fewer total employees and apprentices. Thirty five percent of participants had zero employees or apprentices, and $94 \%$ had three or fewer employees or apprentices (see Appendix Table 1). The eight neighborhoods were chosen because they had enough tailors to form the sample frame, and thus it was not overly costly for consultants and surveyors to visit multiple participants in a day. If two tailors were immediate neighbors, one was randomly chosen to be in the enumeration, to limit the chance the consulting lessons would be overheard by control group tailors. The density of the firms within each neighborhood varied. In one neighborhood, the tailors were right next to each other in market stalls, whereas in other neighborhoods tailors were between a one and ten minute walk apart. Each neighborhood had 20 firms at the baseline. No firms refused to take part in the study. We conducted the individual-level randomization, stratified by the tailor's neighborhood of operation, into consulting/non-consulting in January 2009. The capital grant randomization was done in October 2009, eight months after the consulting began, and was stratified on consulting treatment status 
and the tailor's community of operation. Table 1 reports various baseline values and shows that assignment to the capital or consulting groups is orthogonal to baseline characteristics.

Five of the tailors passed away over the course of the study and six moved, leaving a final sample of 149 for the final follow-up. Attrition is not correlated with treatment status ${ }^{3}$. Though no tailors permanently exited the tailoring business during the course of the study, some tailors did temporarily stop sewing, for health or other reasons. These individuals were included, with profit being either zero or negative (depending on whether all expenses ceased). If a respondent diversified into other activities (for example, selling goods), then we included the revenue, expenses and profits from the additional activities as well (i.e., the sample frame is defined as the individual and any of their enterprises jointly, not merely the tailoring enterprise). Figure 1 provides a timeline of all interventions and data collected in the study.

\section{b) Consulting Treatment}

At the baseline, the microenterprises appeared to be poorly managed, according to standards in the managerial performance literature (Bloom and Van Reenen 2007). Only 17\% of the respondents reported keeping any written financial records, only $7 \%$ reported spending any money on marketing in the last year and only $30 \%$ of shops were rated as very organized by our enumerators. These business practices are correlated at baseline with profitability $(\mathrm{r}=0.26)$, thus suggesting that the measures are indicative of relevant management practices for these enterprises.

From E\&Y in Ghana, we worked with one partner, a director and four consultants ${ }^{4}$. The E\&Y consultants typically work on business advisory engagements in a variety of areas including training, human resources, monitoring and evaluation, and project management. Consultant biographies and examples of prior engagements are in Appendix $\mathrm{B}^{5}$. We worked closely with the consultants to monitor

\footnotetext{
${ }^{3}$ Appendix Table 2 details the sample attrition.

${ }^{4}$ One of the consultants was unavailable after 10 months and was replaced by the consultant who provided the initial two-day training for the E\&Y team.

${ }^{5}$ At the time of the study, the unsubsidized hourly rate for the consultants was US $\$ 75 /$ hour. The plan was to provide 3,000 of consultant hours, but actual total hours were approximately 1200 due to scheduling challenges.
} 
hours spent and to maintain momentum throughout the study. The consultants received a two-day training on microenterprise coaching from Ghana's National Bureau of Small Scale Industries, which frequently provides training to microenterprises in Ghana, on the Bureau's method for training micro-entrepreneurs.

The consultants largely followed an adapted version of this framework (outlined in Appendix C) for technical topics. In addition, consultants were encouraged to act as mentors for the tailors, to think creatively about important business decisions the tailors face, and to work cooperatively with each tailor to develop individually specific ideas for improving the business. Examples can be seen in the consultants' notes in Appendix D.

The training took place at the tailors' shops over the course of one year. After mastering the foundational lesson on record keeping, the consultants helped the tailors calculate profit margins on each item they sold and calculate monthly income statements. Lessons on customer service and employee management occurred throughout the training. For example, if the consultants observed impolite behavior to customers while in the shop, they might take the opportunity to discuss customer service. The pace of the training was set by how quickly tailors mastered the lessons; some never moved past record keeping, while others began preparing cash flow statements and developing detailed plans to finance expansion. The training included both simple, targeted lessons, similar to the "rule of thumb" lessons in Drexler et al (2011), as well as more complicated modules. Examples of the rules of thumb are: "keep your business and personal money separate" and "Buy a second wallet to keep your business money in, so you don't mix it with personal money." Examples of more complicated modules include calculating a monthly profit/loss statement or calculating profits on specific items.

Similar to other studies on business training, some tailors were reluctant to make time for the consultants, and, on average, the tailors covered fewer modules than expected. The average total time spent interacting with each tailor was ten hours over the course of the study (Figure 2) and the maximum hours was 18. This is comparable to Drexler et al (2011), which reports maximum hours of 15 for the 
"rule-of-thumb" group and 18 for the accounting treatment. Few variables predict with statistical significance the number of hours individuals participated, although there is a large differential across consultants, and firms with higher baseline profits had slightly more hours (Appendix Table 3). Each available tailor was visited one to four times per month, with each visit lasting 30 minutes to one hour. The consultants attempted to schedule meetings during slow times to minimize interruption, but inevitably meetings were occasionally disrupted by clients. The consultants used these moments to provide feedback on the tailors' interactions with clients, or to practice the customer service lessons.

In a follow-up survey, participants reported satisfaction with the consulting services. The average reported willingness to pay for the same consultants to continue the training was 5.9 cedis per hour (US $\$ 4$, which is far below the normal rate of the consultants but still large for microentrepreneurs), 2.8 cedis per hour for other consultants to continue the same training (p-value of equality to the E\&Y consultants $<1 \%$ ), and 4.2 cedis per hour for another training of their choice (p-value of equality to the E\&Y consultants $<5 \%$ ). Given the results we have previewed, this willingness to pay is a puzzle, and we posit two possibilities: perhaps respondents felt loyalty to their consultant on a personal level, and the positive report merely reflects that personal relationship, not business value; or, perhaps respondents felt that if they report satisfaction, they would have a chance of receiving some free future services that are more valuable to them (in particular, cash grants).

\section{c) Capital Grant}

At the baseline, $82.5 \%$ of our sample frame had never accessed formal credit markets. Informal finance was similarly rare: over the course of the two-year study, the 160 tailors took only 13 loans from informal sources. The unconditional capital grant was 200 cedis (approximately US \$133). This is a little more than the average tailor's total baseline cash, savings and on-hand money. The capital grant represents, on average, a doubling of the reported cash available for investment for a group of microentrepreneurs who do not have a prior history of accessing formal or informal loans. In terms of 
typically desired investment goods, the capital grant was large enough to buy a mechanical sewing machine. An electric industrial sewing machine costs 300-600 cedis.

Between the randomization stage and the distribution of the capital grant, we verified that the capital grant was not correlated with previous profit data, age, gender, marital status, literacy, years of experience, number of staff, or weekly hours worked. Before the capital grant randomization, two individuals in the initial sample frame of 160 died and four permanently moved out of the study area, leaving 154 respondents in the grant randomization. Of these, 75 were randomly selected to receive capital (37 from the consulting group and 38 from the no consulting group). We asked capital grant recipients to spend the money on their businesses, but made clear they had no repayment obligation.

We included a two-week buffer between the notification and the delivery of money to leave time for the consultants to help their respondents plan how to use the money. However, not all consultants and tailors were available in this window, so not every tailor developed a plan before receiving the money. Control group individuals were provided key chains, t-shirts, and mugs in order to create goodwill and encourage continued participation in surveying.

\section{d) Survey Data}

We conducted eight rounds of surveying over the course of two years. We split the baseline survey into two separate rounds one month apart to reduce the length of each interview (December 2008 and January 2009, Rounds 1 and 2). The first visit focused on financial outcomes and the second visit on business processes and attitudes. The first follow-up was conducted six months later (five months after the consulting began), in July 2009 (Round 3), and primarily included questions on business processes.

In August 2009 (Round 4), we visited the respondents every other day to record how much money they received, how much they spent, how many sales they made, and what type of clothes they sold. We aimed to measure profitability unaffected by changes in the consulting group's understanding of how to calculate profit and ability to recall revenue/expenses, and to improve precision by collecting more 
frequent data. In September 2009 (Round 5), we returned once more to gather recall measures on expenses, revenue and profit for the previous month (August 2009).

We repeated the baseline format for the next round, with surveys in December 2009 (Round 6) and January 2010 (Round 7). The December survey again focused on financial outcomes and the January survey focused on business process outcomes. In December 2010 (Round 8), we conducted the final follow-up, which focused on financial outcomes and business processes. This survey occurred 14 months after the capital drop and 11 months after the consulting stopped.

Reliance on surveying, particularly high frequency surveying, to estimate treatment effects risks bias if the surveying itself alters behavior differentially by treatment group (e.g., see Zwane et al. 2011), or if respondents misreport strategically and differentially by treatment group. This could upwardly or downwardly bias the treatment effects, depending on how the surveying influences information and attention to business decisions and expectations regarding future access to treatments.

\section{Estimation Models and Results}

We examine a series of outcomes related to the interventions: knowledge of standard business, adoption of these practices, investment and savings behavior, and business income and profits. A typical column in the tables that follow reports the results of a cross-sectional regression at time $t$ of the form

$$
y_{i}=\alpha+T_{i} \beta_{1}+y_{i 0} \beta_{2}+N_{i} \beta_{3}+\varepsilon_{i},
$$

where $y_{i}$ is the post treatment outcome for tailor $i . T_{i}$ is a vector of indicators of the intent-to-treat status of tailor $i, y_{i o}$ is the value of the outcome for tailor $i$ in the baseline (either round 1 or round 2, depending upon the measure) and $N_{i}$ is a vector of dummy variables corresponding to the neighborhood in which tailor $i$ operates. This specification permits a flexible examination of the timing of responses to the 
treatments. To estimate average effects across rounds, we pool all follow-up rounds, add round dummies $\mathrm{R}_{\mathrm{i}}$, and report robust standard errors clustered at the individual level:

$$
y_{i t}=\alpha+T_{i t} \beta_{1}+y_{i 0} \beta_{2}+N_{i} \beta_{3}+R_{t} \beta_{4}+\varepsilon_{i t} .
$$

We divide the results into four categories: (a) business literacy and business practices; (b) investments, savings and loans; (c) profitability; and (d) measurement.

\section{a) Business Literacy and Practices}

Eleven months after the end of the consulting period, we find that being assigned to consulting (irrespective of capital treatment status) increased business literacy by an average of 0.3 questions on a 4question quiz (see Appendix E for details on the specific questions for this quiz, and for business practice questions), which is 0.52 of a standard deviation (Table 2, column 1). We also find that tailors who received the consulting treatment adopted the practices discussed in the curriculum, at least temporarily. Columns 3-5 of Table 2 report the results of estimating (1) where $y_{i}$ is an index of the business practices encouraged by the consultants at three different times after consulting began. Business practices were measured by self-reported responses to 35 questions on various practices taught by the consultants. Not all of the questions were asked in every round; for columns 3 through $5, y_{i}$ is a management practice score calculated as the proportion of recommended practices asked about in each round, which the microentrepreneur reports doing. In Round 3 (after six months of consulting), the consulting treatment increased the management practice score by 5.65 percentage points, against a baseline average of $40 \%$ of questions answered correctly ( $\mathrm{p}$-value $<1 \%$ ). By Round 7 (12 months), this effect had diminished to 2.20 (3.27) percentage points for the consulting only (consulting \& capital) treatment, although the reduction from the six-month treatment effect to the 12-month treatment effect is not statistically significant. In Round 8 (two years after consulting began, a year after it ended), the treatment effect further diminished to $0.11(0.23)$ percentage points for the consulting only (consulting \& capital) treatment groups (although still not significantly different from that estimated for Round 3). 
In column 2, we estimate (2) the average effect of the consulting treatment on business practices over all post-consulting rounds. The pooled index for Column 2 was generated by taking the average number of practices adopted across all post-consulting rounds. The average effect of being in the consulting only or consulting \& capital treatment groups over all post-consulting rounds is jointly statistically significant $(\mathrm{p}$-value $=0.05)$.

The consultants' foundational lesson was record keeping, so this was the lesson that the largest number of tailors received and was the one that was returned to most often. As such, if the tailors learned anything from the consulting, we would expect it to be record keeping. We find a strong impact on record keeping ( $\mathrm{p}$-value $<1 \%$ ), with the tailors who received consulting being 45 percentage points more likely to report keeping records at Round 3 (after six months) and those in the consulting only (consulting \& capital) treatment are 26 percentage points (20\%) more likely to keep records in Round 7 (12 months), against a baseline average of 17\%. By Round 8 (24 months), however, the point estimate for the consulting only (consulting \& capital) group decreases to 12 percentage points $(10 \%)$. This decline in the effect of the consulting treatment from round three to round eight is statistically significant ( $\mathrm{p}$-value $<1 \%$ ). Record keeping in the consulting group declined from a high of $63 \%$ of consulting tailors in round 3 to only $28 \%$ in round 8 , so this impact is caused by consulting tailors abandoning record keeping, not control tailors catching up. ${ }^{6}$

Overall, we conclude that the consulting changed both business knowledge and behavior. This finding is in accord with the consultants' qualitative reports (Appendix D), which emphasize the receptiveness of the tailors to the personalized advice. ${ }^{7}$ However, the effect on behavior diminished over time such that

\footnotetext{
${ }^{6}$ There is no evidence that the number of nearby tailors who received the consulting treatment had any impact on the adoption of recommended business practices by either control group or consulting group tailors, although power is low (Appendix Table 4).

${ }^{7}$ For example, the consultants report that the tailors were very receptive to discussions of marketing (e.g., starting to do "sew and sell", where the tailor sews a garment without a specific client in mind in the hope of selling later). The generic bookkeeping lessons required significant effort, and the consultants reported that it was often difficult to "convince" the tailors of its usefulness. These are two examples of advice that may be profitable for some particularly talented tailors, but that on average might reduce profits.
} 
one year after the consulting ended there were no statistically significant differences in behavior between the two consulting groups and the control group.

\section{a) b) Investment}

Table 3 shows estimates of equation (1) when $y_{i}$ is investment flow over the previous 12 months. We have two measures for investment flow. The first is the amount of investment in the specific category the tailor stated he or she would invest in when asked at baseline (details shown in Appendix Table 5). The second measure simply reports the sum of all reported investment flows. The two measures ask subtly different questions: the first examines whether the targeted investment is more likely to happen after relaxing a capital constraint, whereas the second is an aggregate measure of whether the capital grant increased overall investment flows. The second is likely also noisier, as it is a less targeted question and may include investments that are outside the scope of being influenced by the capital grant, yet are incorporated into the measure nonetheless.

In column 1, we see that the capital grant group invested an average of 179 cedis more than the control group in Round 3 (about two months after the grants). The increase in investment for the combined group is lower, only 90 cedis. These two estimates are jointly significantly different from zero (p-value $<10 \%$ ), but are not significantly different from each other. However, a year later (Round 8 , Column 2) the effect disappears. No new capital grant was provided, so new investment would only occur if higher profits from year one led to higher investment in year two, and this did not appear in the data.

Columns 3-10 break the investment results down into one year results (Round 6, Col 3-6) and two year results (Round 8, Col 7-10), and into four outcomes within each time period: total investment, machines, property/shop, and inputs. Converting the outcome measure to investment in a particular category, rather than investment in what each tailor said they would do in the baseline, leads to a loss of statistical power as more noise is introduced. However, the general pattern persists and is consistent with columns 1 and 2. The first year results are generally positive, and the second year results are generally 
negative. The results are very similar when examining stocks of assets as opposed to flows (results available upon request).

Table 4 shows our results on savings. In lieu of investing the capital, the recipients could have saved the money, or, if the capital led to an increase in profits, saved a portion of the increase in profits. We find no statistically significant impacts on total savings or bank savings when pooling all rounds. We find an impact on susu savings $s^{8}$ in the capital \& consulting group, whose average monthly susu savings is almost twice the baseline value of 18.6 cedis a month (point estimate 16.6, standard error 8.4). Looking at the cross-sectional impacts, we find that total savings, bank savings and susu savings were higher in the combined group in the Round 6 follow-up, about two months after the capital drop. We also find that the capital only group has lower total savings than the consulting \& capital group, with this difference statistically significant ( $\mathrm{p}$-value $<10 \%$ ). This might explain the higher point estimate on investment in goals seen in the capital only group - the consultants encouraged capital winners to top up the capital with their own money, saving to do so if necessary.

Table 5 examines net financial flows over the one and two year time horizons. In the months following the capital drop (Column 1), we find a reduction in loan take-up for those in the capital group. We find no long term impact on borrowing (Column 2$)^{9}$.

Columns 3-6 of Table 5 examine the sum of capital flows from all channels. The higher-powered "investment in goal" specification shows increased investment, savings and fewer loans in the capital group ( $\mathrm{p}$-value $<5 \%$ ) and the combined group (p-value $<5 \%$ ) immediately following the grant. The effect of receiving any capital is positive ( $\mathrm{p}$-value $<5 \%$ ), and the consulting \& capital group estimate is higher than the consulting only estimate ( $\mathrm{p}$-value $<5 \%$ ). The point estimates on capital and consulting \& capital are greater than the amount of the capital drop, 200 cedis, but are not significantly different from 200 . The

\footnotetext{
${ }^{8}$ We define susu savings for our tailors as any savings account where someone stops by your shop every day to collect money.

${ }^{9}$ To examine if we are measuring debt at a high borrowing season (and thus may be at a peak of liquidity constraints), we examine seasonality of borrowing and find that borrowing over the three months from September to November is roughly equal to borrowing over the six months from January to June.
} 
total investment specification has qualitatively similar results but larger standard errors. Total uses for the money one year later in Round 8 are primarily negative and not significant.

In summary, short-run knowledge and business practices shift in either of the treatment groups that received consulting towards practices taught by the consultants, and short-run investments are made in the capital grant group. The tailors seem to learn about new techniques from the consultants (or modify their prior beliefs about the profitability of these techniques). Furthermore, the tailors respond to the capital grant by increasing investments and/or savings, suggesting that they are capital constrained. However, in both cases we find that these changes in behavior are short-lived. One year later, there are no significant differences between the capital grant or consulting groups and the control group.

\section{c) Profitability}

An examination of profits provides an explanation for why the tailors abandoned these changes in behavior in the long term. Table 6, column 1 reports the results of estimating (2) where $y_{i t}$ is the tailor's stated income from his or her business. There is no evidence that the consulting treatment is associated with higher profits. Turning to the capital grant group, it seems that the capital grant lowered profits. The point estimate is a post-treatment drop in income of 45 cedis ( $\mathrm{p}$-value $<5 \%$ ), compared to a control group mean of 146 cedis. There is a smaller (and not statistically significant) drop of 23 cedis in income of the consulting \& capital group. The capital only and consulting \& capital point estimates are jointly statistically significant ( $\mathrm{p}$-value $<10 \%$ ), suggesting that the capital grant had negative effect on profits for both groups that received it. ${ }^{10}$

\footnotetext{
${ }^{10}$ Appendix Table 6 shows these results disaggregated by gender. We cannot reject the hypothesis that there is no difference in treatment effects for men and women, although the confidence intervals are large.
} 
We find no statistically significant impacts on revenue and expenses or changes in hours worked (Column 2-5 of Table 6$)^{11}$, nor is there a statistically significant impact on total staff, apprentice use, or paid employees of any of the treatments (columns 6-8). ${ }^{12} 13$

Table 6 examines the average impact of the capital, consulting and combined treatments on posttreatment profits and employment. An examination of the time path of the impacts is also revealing (shown in Figure 3). Recall from our earlier examination of business practices that tailors in the consulting group had adopted the advocated practices by round 3, but that the use of these practices dropped off in round 7 and then again in round 8. Table 7 examines the impact of the treatments on income and expenses by round. We find in column 1 of Table 7 that, by round 3, monthly income in the consulting group is 26 cedis lower than in the control group (p-value $<5 \%$ ). By round 5, income is almost statistically significantly higher in the consulting group, but in later rounds this effect disappears, and there is no difference in income between the consulting group and the control group.

In round 7 , the first post-grant holiday season, the point estimate on income in the capital group is 53 cedis lower than the control and the consulting \& capital group income is 16 cedis lower, but these estimates are not statistically significant. One year later, both groups show large drops in income relative to the control group (point estimates -75 and -98 , standard errors 40 and 45 , for capital versus combined, respectively). Our revenue and expense measures, reported in columns (6-11) are too noisy to permit conclusions to be drawn.

The time path of the profits results mirrors the path of the consulting and capital results. In response to the consulting, the tailors changed their practices and profits decreased. The tailors reverted to their previous practices, and profits reverted to match those of the control group. In response to the capital, the

\footnotetext{
${ }^{11}$ The revenue results and expenses results do not add up to revenue less expenses because some tailors are missing revenue data, but not expense data, or vice versa. If the sample is constrained to tailors who have both revenue and expense data, then the results do sum as expected (not shown).

${ }^{12}$ Not shown, but we also tested the binary dependent variable of any paid employees, rather than the number of paid employees (Column 8). Results were qualitatively similar, and were not statistically different than zero.

${ }^{13}$ Appendix Table 6 presents the results with a fixed effect specification instead. The results are similar, and precision is slightly higher.
} 
tailors invested and, one year later, profits decreased and the tailors stopped investing. This suggests a learning dynamic where, in response to relaxed constraints, the tailors experiment with new techniques, learn that they are not profitable, abandon the techniques and return to their previous scale.

\section{d) Daily data collection versus recall}

If individuals were systematically biased upward or downward in their reports of profits, and the record keeping removes some or all of that bias, we may estimate treatment effects that are mere reporting effects, and not reflective of actual changes in the enterprise. To address this, and to improve statistical power, we conducted a series of high frequency surveys in Round 4, seven months after consulting began. We compared those high frequency visits to questions asked in Round 5, at the end of the month, as recall questions.

In these high frequency surveys, we visited each tailor every other day to ask how much money the tailors received, how much they spent, how many sales they made, what hours they worked, and what types of garments they sold in the prior two days. We collected on average 23.9 days of data per tailor, which is $92.9 \%$ of workdays assuming a six-day workweek. We have an average of 0.9 days fewer data points for the consulting tailors than for the other groups; this difference is not statistically significant.

Table 8 reports the results of these daily visits. There are no statistically significant differences in cash received, cash spent, net cash received (cash in less cash out), the number of hours worked, or the number of sales made. Thus, the average impact of the consulting treatment in August 2009 appears to have been approximately zero and is not likely to be biased by recall ability or knowledge of profits.

To examine whether answers to recall questions are influenced by the consulting, we returned to the tailors in the following month (Round 5) to ask about outcomes in the previous month. The total expenses from Round 5 should therefore roughly correspond to the sum of the cash spent from the daily visits 
data $^{14}$. Appendix Table 8 makes this comparison for revenue (sum of cash in), expenses (sum of cash out), and revenue less expenses (sum of net cash). Column 3 reports the treatment effect of consulting on the difference between the recall amount and the sum of the high frequency visits data. For revenue, expenses and revenue less expenses, we find no statistically significant difference between the two reporting methods. Furthermore, the magnitude of the differences are fairly small, relative to the mean. This gives two insights: (1) the recall data are on average quite similar to the daily visits data; and (2) the consulting group's reports do not appear to be more accurate than the control group.

We also examine the dispersion of the difference between the recall and daily visits numbers by looking at the squared difference (Column 4), and find more dispersion for the consulting group than the control group. This could be a natural byproduct of record keeping combined with highly variable income: individuals do, on average, know their income (whether asked as a recall or daily), and they report that accurately on average whether they have records or not. But for high frequency surveys, if they have records they report exactly what they brought in, whereas without records they instead report an average figure. Thus the variance is higher for the sum of daily observations than the recall for a month, even if the mean is the same, for those that keep daily revenue records.

\section{Discussion of Power}

We focus our discussion of statistical power on the profit results. The estimate for the effect of the consulting only treatment on stated income is an increase of $0.9(\mathrm{se}=21.4)$ cedis over a control group mean of 146 (Column 1 of Table 6). Thus, the upper bound of the $95 \%$ confidence interval is 41 cedis, a $28 \%$ increase over the control group mean. If we consider the impact of receiving any consulting, as opposed to the separate impact of consulting versus consulting and capital combined, the upper bound of

\footnotetext{
${ }^{14}$ From an accounting standpoint, expenses and cash spent should not be equal, but we expect the difference between accounting revenue/expenses and cash in/out to be relatively minor in our case.
} 
the $95 \%$ confidence interval is $23 \%$ of mean control group profits ${ }^{15}$. Although this is not trivial, it is small relative to the cost of the consultants' labor.

More importantly, we compare our $95 \%$ confidence interval to results from other studies. McKenzie and Woodruff (2013) review business training experiments and report the impact on profits and revenue of ten different estimates (of which only two report statistically significant results). We can reject (at 5\%) impacts as large as the two statistically significant results from comparable studies. We can also reject a third large but not statistically significant result. The average impact from this table of ten estimates is $10.5 \%$ (Appendix Table 9). Weighting these point estimates by sample size, the average impact is $9.5 \%$. We cannot reject the null that the impact of any consulting in our study is equal to the simple average or the weighted average by sample size (p-values of $14 \%$ and $17 \%$ ).

The capital grant experiment has fewer comparable studies. The two most relevant capital grant studies are de Mel et al. (2008) and Fafchamps et al. (2014). The de Mel et al. (2008) study reports average impacts of $20 \%$ and $37 \%$ of real baseline profits (Tables 1 and 2). Fafchamps et al. (2014) report average impacts of $0 \%-13.7 \%$ in various specifications (Tables 2-3). Fafchamps et al. (2014) is particularly important comparison to our study, since it is located in the same city, during an overlapping time. A third related study is Blattman et al. (2013), which reports a $41 \%$ increase in real net cash earnings over four years from capital grants to underemployed youth that aimed to increase microenterprise formation.

The $95 \%$ confidence interval of our point estimate for the capital only treatment is $-66 \%$ to $-1 \%$, which includes neither the simple $(27 \%$ increase in profits) nor the weighted average $(25 \%$ increase in profits) of the results in found in de Mel et al (2008), Fafchamps et al (2014) and Blattman et al. (2013).

\footnotetext{
${ }^{15}$ This comes from a regression that combines consulting only and capital only into a single, "any consulting" group (not reported). The "any consulting" point estimate from this regression is -10.4 and the standard error is 17.4.
} 


\section{Conclusion}

Canonical theories of poverty traps suggest that credit and managerial capital constraints inhibit investment and thus profits. To examine these hypotheses, we provided large grants of capital and management consulting, separately and combined, to urban microenterprises in Ghana. We find that the entrepreneurs invest the cash grants in their businesses and adopt the management practices advocated by the businesses consultants. But there is no evidence that these changes were associated with increases in profits, and in the long run - about one year after the interventions were completed - these microenterprises looked no different on average than the control group. This evidence is consistent with microenterprises operated by heterogeneous entrepreneurs who are unsure about the profitability of expanding their business or of using innovative managerial practices and face capital and managerial capital constraints on investment.

Naturally, other theories could explain the results. First, we emphasize again that the true effects of the interventions on investment and profits may be modest and positive (or modest and negative). Second, it could be that the optimal firm size in this setting and industry is indeed micro. Although then the puzzle remains, why did the tailors take on investment and change business practices, if not to learn their optimal size? Perhaps the investment and changes in business practices were due to the persuasive efforts of the implementing NGO.

Critical questions remain. We suggest five directions for further research: (1) more detailed measurement of attitudes, preferences and expectations, both from surveys and from laboratory experiments in the field, to shed light on mechanisms; (2) heterogeneity with respect to type of entrepreneur and individual; (3) dynamics and determinants of learning (including differences in program design); (4) market selection for interventions; and (5) general equilibrium and competitive effects.

To understand the mechanisms through which interventions do or do not work, researchers can resort to experimental variation (e.g., sub-treatments randomized within studies to remove, or add, specific components) or to detailed measurement of process changes that can then help rule-in or -out the 
possibility of different mechanisms. For example, in our setting, we put forward a conjecture that individuals required either capital or mentoring in order to be willing to experiment with larger more ambitious approaches to business, but that they then found (on average) failure with such approaches. Measurement of confidence and willingness to take on business risks could have shed insight on this, had we had it both prior to the study, immediately upon the interventions and at the end. This approach was taken in Berge, Bjorvatn and Tungooden (2014); they find that females have weaker results from receiving capital and training, and that women were less competitive at endline. In associated work, the authors find that competitiveness as measured in their game does predict business success (Berge et al. 2015). Further research on this is required in order to determine if the weaker treatment effects for women are a consequence of the lower levels of competitiveness, or some other factor.

Second, heterogeneity is at the core of our interpretation of these results. One reason for the mixed results in the studies discussed in Section IV may be that the positive impacts are most pronounced in a few strong outliers, but ones that are difficult to predict beforehand. Are there diagnostics that could substitute for the costly experimentation otherwise required to distinguish a minority who can flourish at a larger scale from those who will not? For policy, such diagnostics could be used to target more efficiently, which is particularly critical if the intervention is great for some and bad for others. The power calculations for this study were based on large minimal detectable average effect sizes that, even if true, would likely not have permitted testing for heterogeneity across respondents based on observables.

Despite the null, or negative, results put forward here, the question we believe remains critical for further studies: are there identifiable individuals, perhaps based on gender, prior experience in enterprise, household structure, educational level, cognitive ability, etc., for which financial or managerial capital or both are binding constraints? Several similar studies find considerable heterogeneity. For example, three studies find lower (often indistinguishable from zero) returns for women from enterprise grants, and positive returns for men (e.g., Berge, Bjorvatn, and Tungooden 2014; de Mel, McKenzie, and Woodruff 2008; Fafchamps et al. 2014). Our results, in combination with the heterogeneity found elsewhere, 
motivate closer attention to stronger theory which can structure pooled or meta-analysis across studies, or much larger studies.

Third, there are related questions pertaining to the process of learning. We have found that entrepreneurs tried what was given to them (either advice from consulting, and/or investment from cash grants), but then learned that neither was profitable, and therefore stopped. Clearly there are many channels for learning: from one's own experience, from a teacher in a classroom setting, from a paid consultant, from an NGO, from a mentor with experience in one's own industry, etc. How do these different channels of learning differ in effectiveness, and why? Could it be that better advice through a more effective channel would have had more positive impacts and long lasting changes in behavior?

Fourth, markets differ in terms of competitiveness, and interventions such as those discussed here should generate different impacts depending on the competitive landscape. Perhaps the tailor industry is in perfectly competitive equilibrium, but some other industry is less so in the same geography. Understanding, and then testing, the underlying market factors that are necessary for success is important both for validating our models and for establishing diagnostics for policymakers and institutions interested in improving the industrial performance. For example, markets with potential product differentiation or skilled and available supply of labor may be ripe for such interventions, but those with fully competitive markets less so.

Lastly, few if any studies have satisfactorily tackled the impact of improving the performance of one set of firms on market equilibrium outcomes. The challenge is simple and obvious: if helping one firm greatly improve its performance yields a smidgeon of negative impacts for 100 other firms, it will be difficult to have sufficient statistical power to measure the smidgeons. Theory can help, as well as a focus on collecting data about the channels through which changes occur within the firm, and by extension, the actual changes in services that customers receive. For example, if the intervention primarily teaches better persuasive marketing, but not informative marketing, then business is likely simply being shifted from the 
less persuasive firm to the more persuasive one. If, on the other hand, product quality has increased, or costs have been lowered, then equilibrium benefits are likely accruing. This is an important area for further research in the entrepreneurship development literature, for both research and policy. 


\section{References}

Angelucci, Manuela, Dean Karlan, and Jonathan Zinman. 2015. "Microcredit Impacts: Evidence from a Randomized Microcredit Program Placement Experiment by Compartamos Banco." American Economic Journal: Applied Economics 7 (1): 151-82. doi:10.1257/app.20130537.

Attanasio, Orazio, Britta Augsburg, Ralph De Haas, Emla Fitzsimons, and Heike Harmgart. 2015. "The Impacts of Microfinance: Evidence from Joint-Liability Lending in Mongolia." American Economic Journal: Applied Economics 7 (1): 90-122. doi:10.1257/app.20130489.

Augsburg, Britta, Ralph De Haas, Heike Harmgart, and Costas Meghir. 2015. "The Impacts of Microcredit: Evidence from Bosnia and Herzegovina." American Economic Journal: Applied Economics 7 (1): 183-203. doi:10.1257/app.20130272.

Banerjee, Abhijit, Esther Duflo, Rachel Glennerster, and Cynthia Kinnan. 2015. "The Miracle of Microfinance? Evidence from a Randomized Evaluation." American Economic Journal: Applied Economics 7 (1): 22-53. doi:10.1257/app.20130533.

Banerjee, Abhijit, Dean Karlan, and Jonathan Zinman. 2014. "Six Randomized Evaluations of Microcredit: Introduction and Further Steps."

Beaman, Lori, Dean Karlan, Bram Thuysbaert, and Christopher Udry. 2014. "Self-Selection into Credit Markets: Evidence from Agriculture in Mali." Working Paper.

Berge, Lars, Kjetil Bjorvatn, Armando Jose Garcia Pires, and Bertil Tungodden. 2015. "Competitive in the Lab, Successful in the Field?" Journal of Economic Behavior \& Organization. Accessed March 26. doi:10.1016/j.jebo.2014.11.014.

Berge, Lars, Kjetil Bjorvatn, and Bertil Tungooden. 2014. "Human and Financial Capital for Microenterprise Development: Evidence from a Field and Lab Experiment." Management Science forthcoming.

Blattman, Christopher, Nathan Fiala, and Sebastian Martinez. 2013. Credit Constraints, Occupational Choice and the Process of Development : Long Run Evidence from Cash Transfers in Uganda. 81224. The World Bank. http://documents.worldbank.org/curated/en/2013/08/18305314/credit-constraintsoccupational-choice-process-development-long-run-evidence-cash-transfers-uganda.

Bloom, Nicholas, Benn Eifert, Aprajit Mahajan, David McKenzie, and John Roberts. 2012. "Does Management Matter? Evidence from India." The Quarterly Journal of Economics, November, qjs044. doi:10.1093/qje/qjs044.

Bloom, Nicholas, and John Van Reenen. 2007. "Measuring and Explaining Management Practices across Firms and Countries." Quarterly Journal of Economics 122 (4): 1341-1408.

Bruhn, Miriam, Dean Karlan, and Antoinette Schoar. 2013. "The Impact of Consulting Services on Small and Medium Enterprises: Evidence from a Randomized Trial in Mexico." Working Paper, March.

Bruhn, Miriam, and Bilal Zia. 2011. "Stimulating Managerial Capital in Emerging Markets: The Impact of Business and Financial Literacy for Young Entrepreneurs." World Bank Policy Research Working Paper No. 5642.

Calderon, Gabriela, Jesse Cunha, and Giacomo de Giorgi. 2013. "Business Literacy and Development: Evidence from a Randomized Trial in Rural Mexico."

Crépon, Bruno, Florencia Devoto, Esther Duflo, and William Pariente. 2015. "Estimating the Impact of Microcredit on Those Who Take It Up: Evidence from a Randomized Experiment in Morocco." American Economic Journal: Applied Economics 7 (1): 123-50. doi:10.1257/app.20130535.

De Mel, Suresh, David McKenzie, and Christopher Woodruff. 2008. "Returns to Capital in Microenterprises: Evidence from a Field Experiment." Quarterly Journal of Economics 123 (4): 1329-72. 
Drexler, Alejandro, Greg Fischer, and Antoinette Schoar. 2011. "Keeping It Simple: Financial Literacy and Rules of Thumb."

Fafchamps, Marcel, David McKenzie, Simon Quinn, and Christopher Woodruff. 2014. "Microenterprise Growth and the Flypaper Effect: Evidence from a Randomized Experiment in Ghana." Journal of Development Economics 106 (January): 211-26. doi:10.1016/j.jdeveco.2013.09.010.

Giné, Xavier, and Ghazala Mansuri. 2011. "Money or Ideas? A Field Experiment on Constraints to Entrepreneurship in Rural Pakistan."

Karlan, Dean, Ryan Knight, and Christopher Udry. 2012. "Hoping to Win, Expected to Lose: Theory and Lessons on Micro Enterprise Development." NBER Working Paper 18325 (August). http://www.nber.org/papers/w18325.

Karlan, Dean, Isaac Osei-Akoto, Robert Darko Osei, and Christopher R. Udry. 2013. "Agricultural Decisions after Relaxing Credit and Risk Constraints." Quarterly Journal of Economics, Forthcoming. doi:10.2139/ssrn.2169548.

Karlan, Dean, and Martin Valdivia. 2011. "Teaching Entrepreneurship: Impact of Business Training on Microfinance Clients and Institutions." Review of Economics and Statistics 93 (2): 510-27.

Karlan, Dean, and Jonathan Zinman. 2010. "Expanding Credit Access: Using Randomized Supply Decisions to Estimate the Impacts." Review of Financial Studies 23 (1): 433-64.

- - - 2011. "Microcredit in Theory and Practice: Using Randomized Credit Scoring for Impact Evaluation." Science 332 (6035): 1278-84. doi:10.1126/science.1200138.

Tarozzi, Alessandro, Jaikishan Desai, and Kristin Johnson. 2015. "The Impacts of Microcredit: Evidence from Ethiopia." American Economic Journal: Applied Economics 7 (1): 54-89. doi:10.1257/app.20130475.

Valdivia, Martin. 2014. "Business Training Plus for Female Entrepreneurship? Short and Medium-Term Experimental Evidence from Peru." Journal of Development Economics forthcoming.

Zwane, A. P., J. Zinman, E. Van Dusen, W. Pariente, C. Null, E. Miguel, M. Kremer, et al. 2011. "Being Surveyed Can Change Later Behavior and Related Parameter Estimates." Proceedings of the National Academy of Sciences 108 (5): 1821-26. doi:10.1073/pnas.1000776108. 
VII. Tables and Figures

Figure 1: Timeline

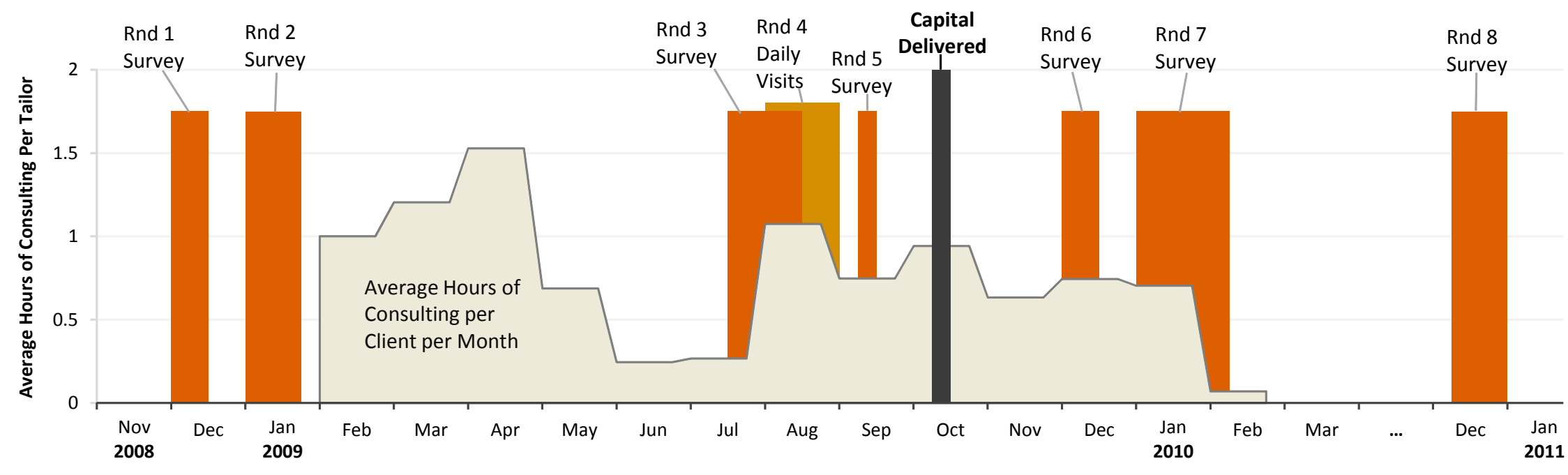

\begin{tabular}{|c|c|c|c|c|c|c|c|c|}
\hline \multicolumn{9}{|l|}{ Survey Modules } \\
\hline$\underline{\text { All Modules }}$ & $\underline{\text { Rnd } 1}$ & $\underline{\text { Rnd } 2}$ & $\underline{\text { Rnd } 3}$ & $\underline{\text { Rnd } 4}$ & $\underline{\text { Rnd } 5}$ & $\underline{\text { Rnd } 6}$ & $\underline{\text { Rnd } 7}$ & $\underline{\text { Rnd } 8}$ \\
\hline Income & Income & & Income & & Income & Income & Income & Income \\
\hline Biz Overview & Biz Overview & & Biz Overview & & & Biz Overview & & Biz Overview \\
\hline Staff & Staff & & & & & Staff & & Staff \\
\hline Assets & Assets & & & & & Assets & & Assets \\
\hline Finance & Finance & & Finance & & & Finance & & Finance \\
\hline Operations & Operations & & Operations & & & & Operations & \\
\hline Rev/Expense & Rev/Expense & & & & Rev/Expense & Rev/Expense & & Rev/Expense \\
\hline Products & & Products & Products & & Products & Products & & Products \\
\hline Marketing & & Marketing & & & & & Marketing & \\
\hline Skills/Formality & & Skills/Formality & & & & & Formality & \\
\hline Household & & Household & & & & & Household & \\
\hline Financial Literacy & & Financial Literacy & & & & & & FInancial LIteracy \\
\hline Attitudes & & Attitudes & & & & & Attitudes & \\
\hline Social Networks & & Social Networks & & & & & & \\
\hline Games & & Games & & & & & Games & \\
\hline Bookkeeping & & & Bookkeeping & & & & Bookkeeping & Bookkeeping \\
\hline Quality of Consulting & & & & & & & & Quality of Consulting \\
\hline Daily Logs & & & & Daily Logs & & & & \\
\hline & & & & 27 & & & & \\
\hline
\end{tabular}


Figure 2: Histogram of hours of consulting per tailor

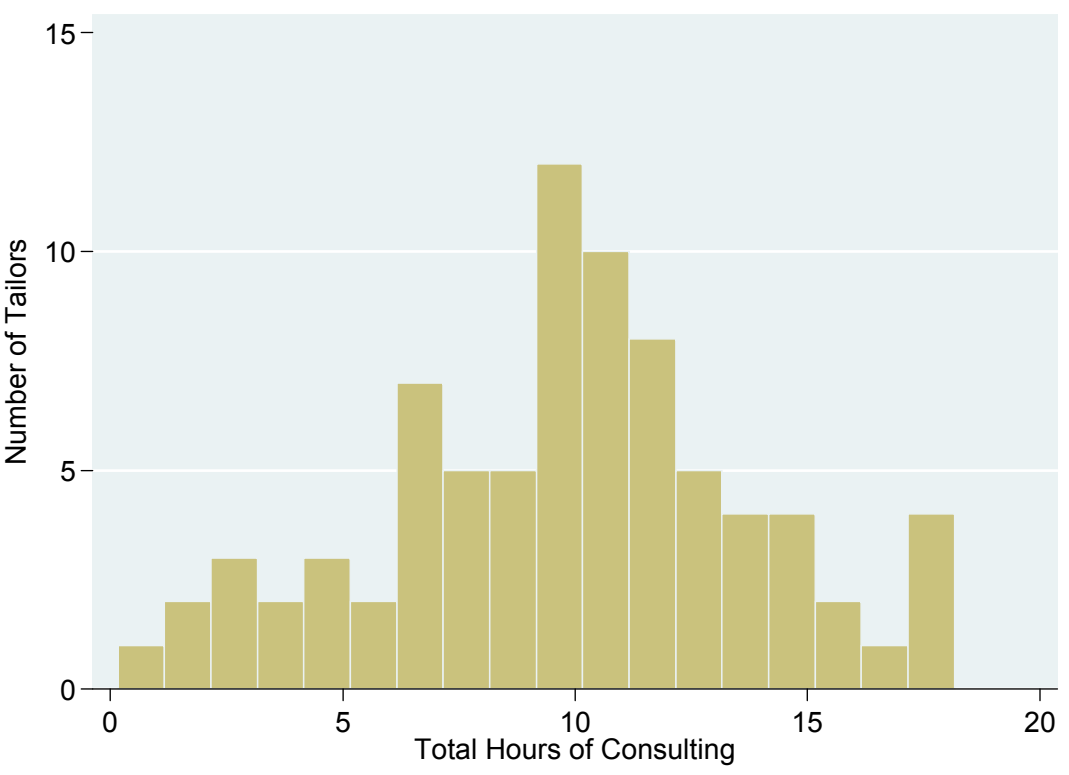


Figure 3: Mean Income by Month

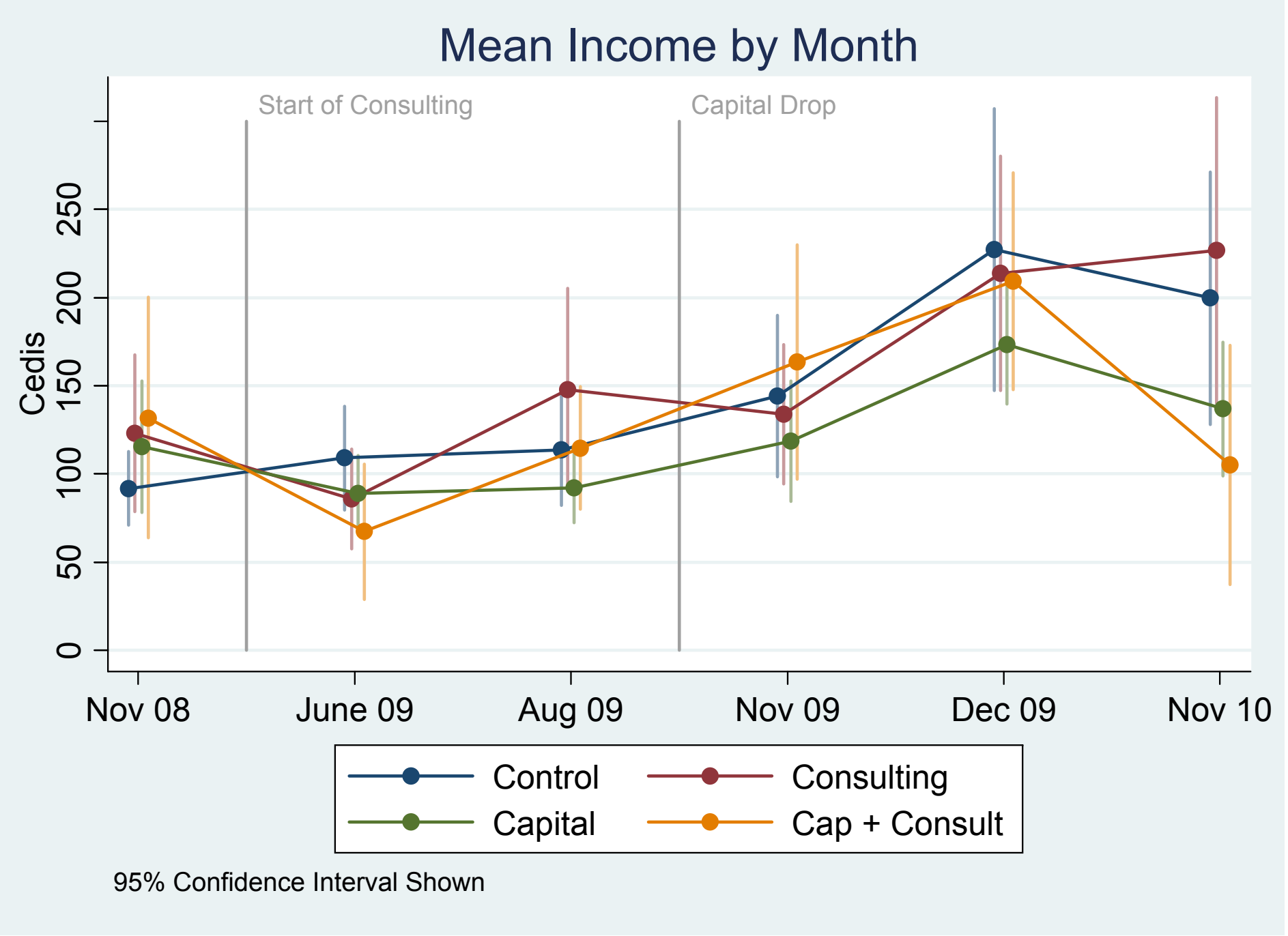


Table 1: Baseline Summary Statistics and Randomization Check

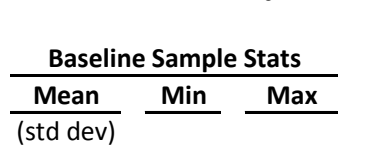

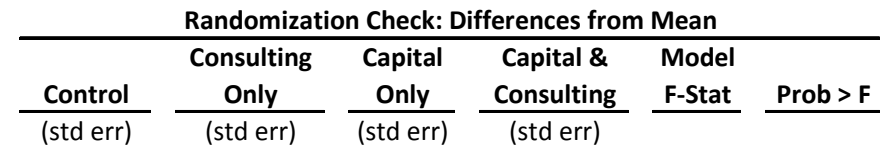

(1) (2) (3)

(4)

(5)

(6)

(7)

(8)

(9)

\begin{tabular}{|c|c|c|c|c|c|c|c|c|c|}
\hline Number of Tailors & 160 & & & 45 & 41 & 36 & 36 & & \\
\hline Male & $\begin{array}{r}0.43 \\
(0.5)\end{array}$ & 0 & 1 & $\begin{array}{r}0.00777 \\
(0.0549)\end{array}$ & $\begin{array}{r}-0.0166 \\
(0.0549)\end{array}$ & $\begin{array}{l}0.0424 \\
(0.0570)\end{array}$ & $\begin{array}{r}-0.0424 \\
(0.0586)\end{array}$ & 0.297 & 0.880 \\
\hline Age & $\begin{array}{r}35.29 \\
(7.8)\end{array}$ & 22 & 76 & $\begin{array}{l}0.125 \\
(1.181)\end{array}$ & $\begin{array}{r}-1.655 \\
(1.181)\end{array}$ & $\begin{array}{l}1.816 \\
(1.227)\end{array}$ & $\begin{array}{r}-0.204 \\
(1.278)\end{array}$ & 1.048 & 0.385 \\
\hline Married & $\begin{array}{r}0.56 \\
(0.5)\end{array}$ & 0 & 1 & $\begin{array}{r}0.120 \\
(0.0772)\end{array}$ & $\begin{array}{l}0.0229 \\
(0.0772)\end{array}$ & $\begin{array}{l}-0.115 \\
(0.0802)\end{array}$ & $\begin{array}{r}-0.00694 \\
(0.0824)\end{array}$ & 1.148 & 0.336 \\
\hline Literacy & $\begin{array}{l}1.30 \\
(1.0)\end{array}$ & 1 & 5 & $\begin{array}{l}0.101 \\
(0.166)\end{array}$ & $\begin{array}{r}0.0421 \\
(0.164)\end{array}$ & $\begin{array}{r}-0.0561 \\
(0.172)\end{array}$ & $\begin{array}{r}-0.0708 \\
(0.177)\end{array}$ & 0.175 & 0.951 \\
\hline Number of Children & $\begin{array}{l}1.24 \\
(1.3)\end{array}$ & 0 & 6 & $\begin{array}{r}0.343^{*} \\
(0.205)\end{array}$ & $\begin{array}{r}-0.120 \\
(0.205)\end{array}$ & $\begin{array}{r}-0.103 \\
(0.219)\end{array}$ & $\begin{array}{r}-0.0420 \\
(0.222)\end{array}$ & 0.853 & 0.494 \\
\hline Shop is cement & $\begin{array}{r}0.21 \\
(0.4)\end{array}$ & 0 & 1 & $\begin{array}{l}0.0620 \\
(0.0630)\end{array}$ & $\begin{array}{l}0.0620 \\
(0.0630)\end{array}$ & $\begin{array}{r}-0.0484 \\
(0.0654)\end{array}$ & $\begin{array}{r}-0.0951 \\
(0.0672)\end{array}$ & 1.123 & 0.348 \\
\hline Income last month & $\begin{array}{r}113.99 \\
(122.9)\end{array}$ & 0 & 1000 & $\begin{array}{r}-22.20 \\
(19.94)\end{array}$ & $\begin{array}{l}8.924 \\
(20.75)\end{array}$ & $\begin{array}{l}1.570 \\
(22.01)\end{array}$ & $\begin{array}{l}17.84 \\
(22.74)\end{array}$ & 0.511 & 0.728 \\
\hline Ave Monthly Revenue & $\begin{array}{r}240.21 \\
(224.9)\end{array}$ & 12 & 2000 & $\begin{array}{l}3.392 \\
(35.79)\end{array}$ & $\begin{array}{r}61.50^{*} \\
(35.35)\end{array}$ & $\begin{array}{r}-36.21 \\
(38.26)\end{array}$ & $\begin{array}{r}-32.62 \\
(38.81)\end{array}$ & 1.160 & 0.331 \\
\hline Monthly Expenses & $\begin{array}{r}247.66 \\
(262.9)\end{array}$ & 3 & 1712 & $\begin{array}{l}33.66 \\
(41.63)\end{array}$ & $\begin{array}{r}-16.56 \\
(41.63)\end{array}$ & $\begin{array}{l}6.848 \\
(43.24)\end{array}$ & $\begin{array}{r}-19.59 \\
(44.42)\end{array}$ & 0.258 & 0.904 \\
\hline Apprentices & $\begin{array}{r}0.86 \\
(1.1)\end{array}$ & 0 & 5 & $\begin{array}{r}-0.204 \\
(0.171)\end{array}$ & $\begin{array}{r}0.430^{* *} \\
(0.171)\end{array}$ & $\begin{array}{r}-0.205 \\
(0.178)\end{array}$ & $\begin{array}{r}-0.0292 \\
(0.183)\end{array}$ & 2.263 & 0.0649 \\
\hline Employees & $\begin{array}{r}0.35 \\
(0.6)\end{array}$ & 0 & 4 & $\begin{array}{r}-0.00854 \\
(0.0984)\end{array}$ & $\begin{array}{r}-0.0329 \\
(0.0984)\end{array}$ & $\begin{array}{l}0.124 \\
(0.102)\end{array}$ & $\begin{array}{r}-0.1000 \\
(0.105)\end{array}$ & 0.623 & 0.647 \\
\hline Fixed Assets & $\begin{array}{r}1566.01 \\
(1975.8)\end{array}$ & 110 & 20230 & $\begin{array}{r}-72.22 \\
(312.1)\end{array}$ & $\begin{array}{r}-125.3 \\
(312.1)\end{array}$ & $\begin{array}{l}457.0 \\
(324.2)\end{array}$ & $\begin{array}{r}-260.8 \\
(333.0)\end{array}$ & 0.704 & 0.590 \\
\hline Working Capital & $\begin{array}{r}184.02 \\
(263.6)\end{array}$ & 0 & 2000 & $\begin{array}{l}48.96 \\
(41.23)\end{array}$ & $\begin{array}{l}42.38 \\
(41.74)\end{array}$ & $\begin{array}{r}-68.07 \\
(44.00)\end{array}$ & $\begin{array}{r}-16.59 \\
(44.62)\end{array}$ & 1.243 & 0.295 \\
\hline Keeps Records & $\begin{array}{r}0.17 \\
(0.4)\end{array}$ & 0 & 1 & $\begin{array}{r}-0.0224 \\
(0.0594)\end{array}$ & $\begin{array}{r}-0.0468 \\
(0.0594)\end{array}$ & $\begin{array}{l}0.0681 \\
(0.0617)\end{array}$ & $\begin{array}{l}0.0257 \\
(0.0634)\end{array}$ & 0.536 & 0.710 \\
\hline Registered Business & $\begin{array}{r}0.53 \\
(0.5)\end{array}$ & 0 & 1 & $\begin{array}{l}0.0297 \\
(0.0788)\end{array}$ & $\begin{array}{r}0.00534 \\
(0.0788)\end{array}$ & $\begin{array}{l}0.0214 \\
(0.0818)\end{array}$ & $\begin{array}{r}-0.00347 \\
(0.0841)\end{array}$ & 0.0543 & 0.994 \\
\hline Has Ever Taken a Loan & $\begin{array}{r}0.11 \\
0.3\end{array}$ & 0 & 1 & $\begin{array}{r}-0.0331 \\
(0.0479)\end{array}$ & $\begin{array}{r}-0.0575 \\
(0.0479)\end{array}$ & $\begin{array}{r}0.131^{* * *} \\
(0.0498)\end{array}$ & $\begin{array}{r}-0.0229 \\
(0.0511)\end{array}$ & 2.251 & 0.0662 \\
\hline Social Network Size & $\begin{array}{r}2.81 \\
(2.6)\end{array}$ & 0 & 13 & $\begin{array}{r}-0.0808 \\
(0.289)\end{array}$ & $\begin{array}{r}0.0168 \\
(0.289)\end{array}$ & $\begin{array}{r}-0.0757 \\
(0.300)\end{array}$ & $\begin{array}{l}0.271 \\
(0.308)\end{array}$ & 0.230 & 0.922 \\
\hline Digits Backward & $\begin{array}{r}3.11 \\
(0.9)\end{array}$ & 1 & 6 & $\begin{array}{r}-0.0881 \\
(0.0997)\end{array}$ & $\begin{array}{r}-0.0637 \\
(0.0997)\end{array}$ & $\begin{array}{r}0.0980 \\
(0.104)\end{array}$ & $\begin{array}{r}0.0264 \\
(0.106)\end{array}$ & 0.537 & 0.709 \\
\hline
\end{tabular}

Notes: Standard errors and F-Stat are from a regression of de-meaned baseline values against all four groups with no constant. Baseline standard deviations are reported below baseline means. 
Table 2: Business Literacy and Practices

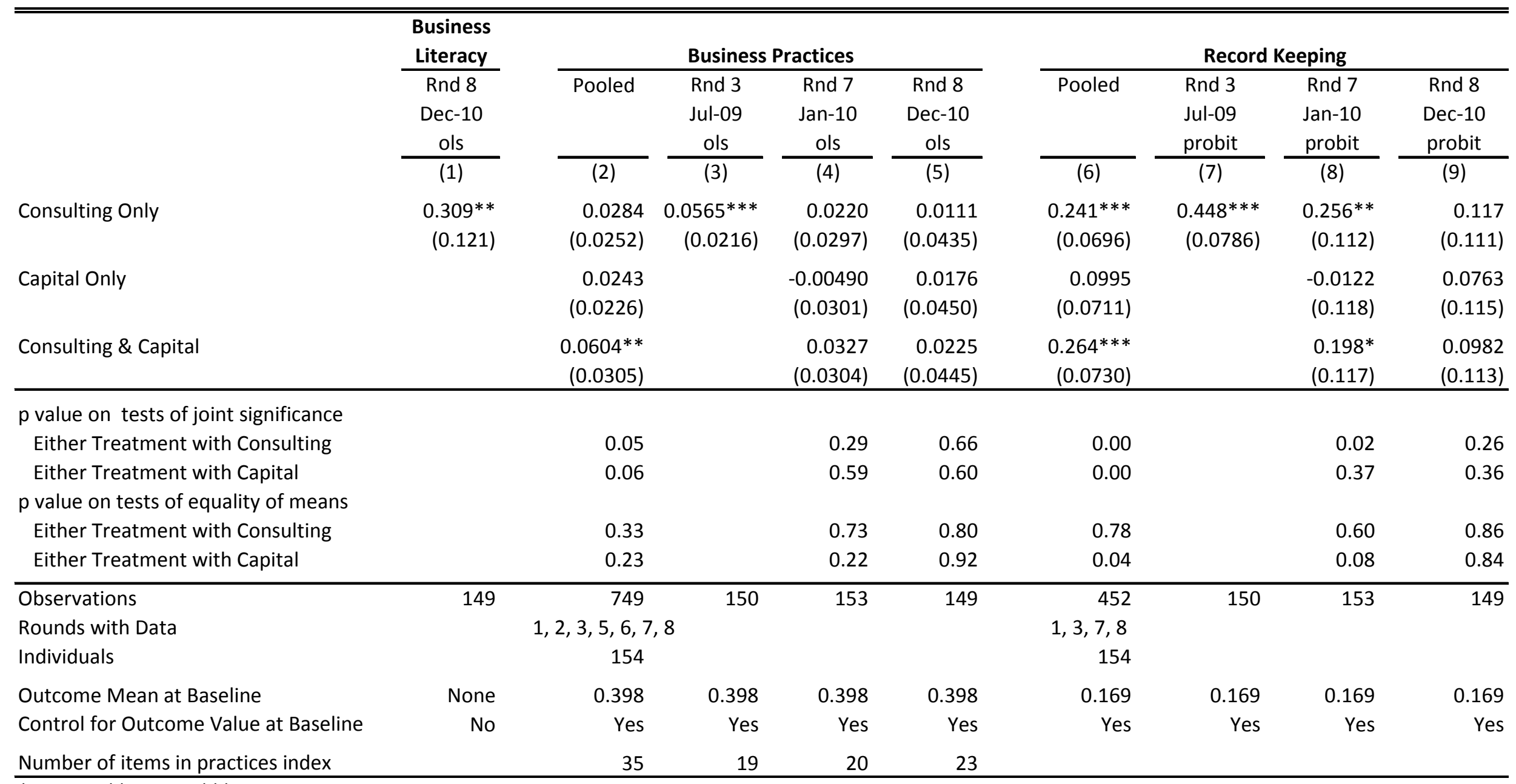

Number of items in practices index

Standard errors in parentheses, clustered by individual where more than one round is combined (columns 2 and 6 ).

All regressions include controls for baseline value (except column 1, which has no baseline measurement) and stratification variables (neighborhood).

Business literacy is the number of answers correct on a 4 question test of business literacy.

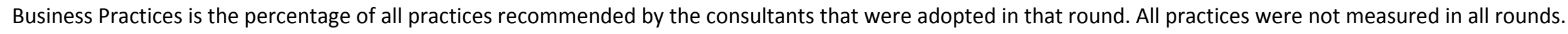
Record Keeping is whether the respondent stated that they keep financial records.

Round-by-round record keeping regressions are probit models with marginal effects reported. 
Table 3: Investment Flows

OLS

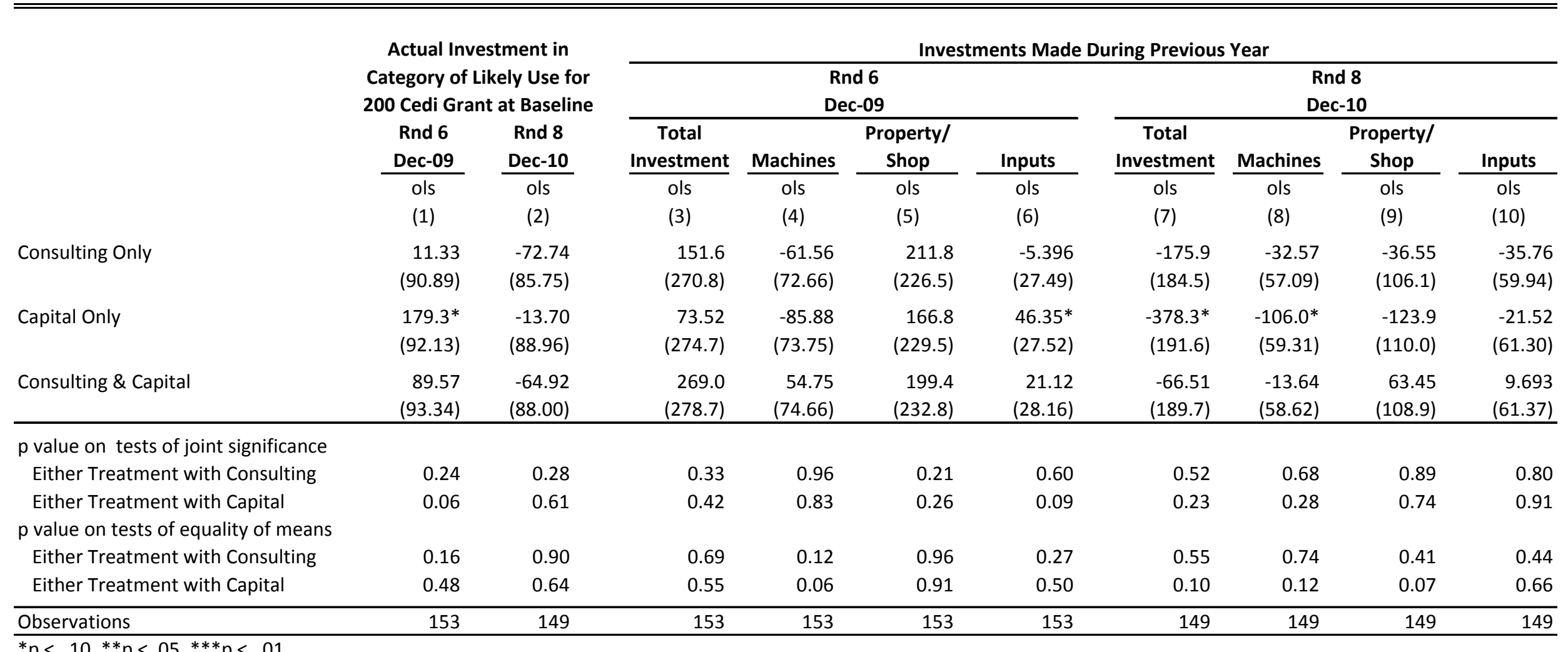

${ }^{*} \mathrm{p}<.10,{ }^{* *} \mathrm{p}<.05,{ }^{* * *} \mathrm{p}<.01$

Standard errors in parenthesis

Controls for baseline value and stratification variables (neighborhood) in all regressions.

All variables winsorized at the highest $1 \%$

See Appendix Table 3 for breakdown of likely investment categories at baseline. 
Table 4: Savings

OLS

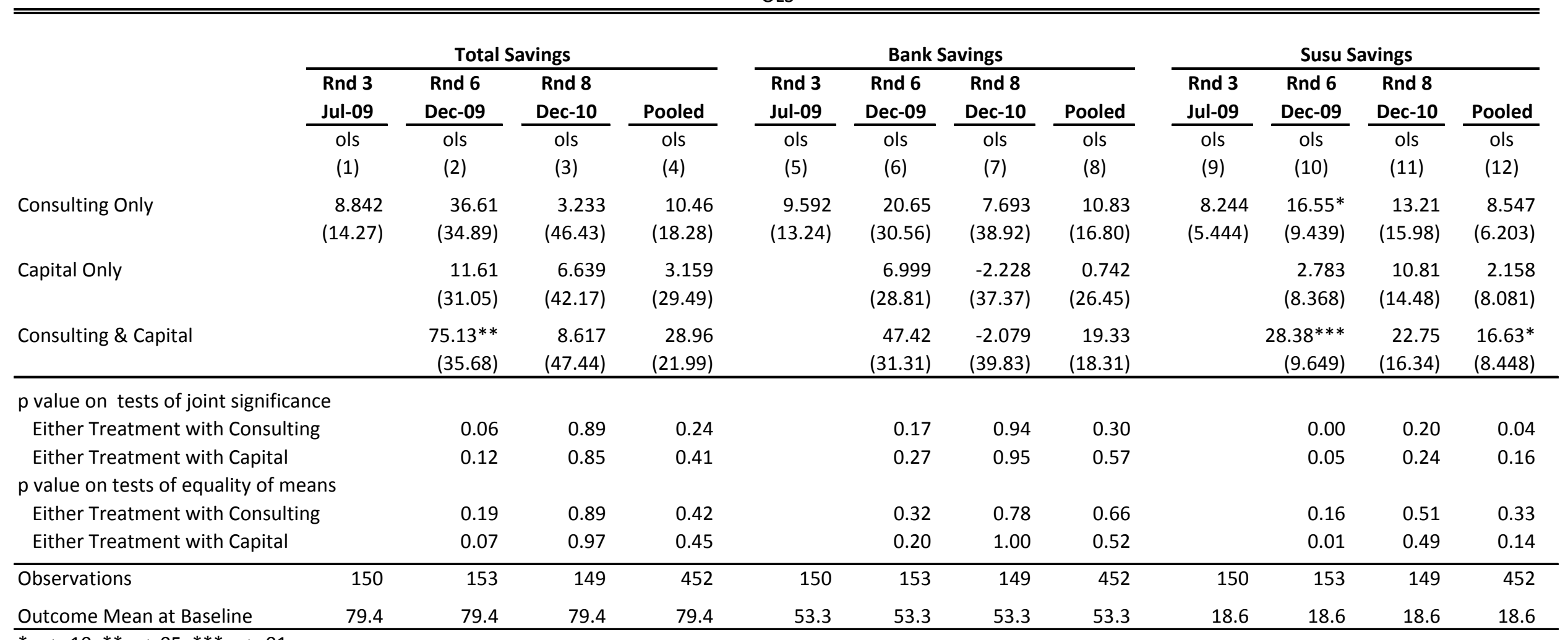

$* \mathrm{p}<.10, * * \mathrm{p}<.05, * * * \mathrm{p}<.01$

Robust standard errors in parentheses, clustered by individual where more than one round is combined (columns 4,8 and 12 ).

Controls for baseline value and stratification variables (neighborhood) in all regressions. 
Table 5: Change in Net Financial Flows, All Channels

OLS

\begin{tabular}{|c|c|c|c|c|c|c|}
\hline & \multicolumn{2}{|c|}{ Loan Amounts } & \multicolumn{2}{|c|}{$\begin{array}{l}\text { Investment in Goal, } \\
\text { Savings, and } \\
\text { Avoided Loans }\end{array}$} & \multicolumn{2}{|c|}{$\begin{array}{l}\text { Total Investment, } \\
\text { Savings, and } \\
\text { Avoided Loans }\end{array}$} \\
\hline & 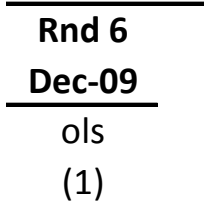 & $\begin{array}{c}\begin{array}{c}\text { Rnd } 8 \\
\text { Dec-10 }\end{array} \\
\text { ols } \\
(2)\end{array}$ & 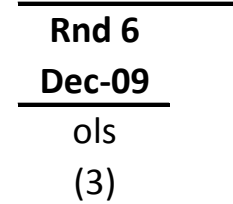 & $\begin{array}{c}\begin{array}{c}\text { Rnd 8 } \\
\text { Dec-10 }\end{array} \\
\text { ols } \\
\text { (4) }\end{array}$ & 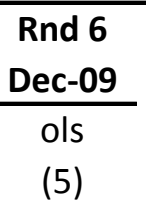 & $\begin{array}{c}\begin{array}{c}\text { Rnd 8 } \\
\text { Dec-10 }\end{array} \\
\text { ols } \\
(6)\end{array}$ \\
\hline Consulting Only & $\begin{array}{r}-55.82 \\
(55.47)\end{array}$ & $\begin{array}{r}-31.71 \\
(88.69)\end{array}$ & $\begin{array}{r}67.35 \\
(113.1)\end{array}$ & $\begin{array}{r}-42.43 \\
(113.9)\end{array}$ & $\begin{array}{r}211.6 \\
(286.7)\end{array}$ & $\begin{array}{r}-54.14 \\
(149.3)\end{array}$ \\
\hline Capital Only & $\begin{array}{r}-135.6 * * \\
(55.40)\end{array}$ & $\begin{array}{r}21.75 \\
(90.56)\end{array}$ & $\begin{array}{r}326.2^{* * *} \\
(114.6)\end{array}$ & $\begin{array}{r}-43.32 \\
(118.2)\end{array}$ & $\begin{array}{r}191.5 \\
(290.6)\end{array}$ & $\begin{array}{r}-245.6 \\
(154.9)\end{array}$ \\
\hline Consulting \& Capital & $\begin{array}{r}-85.09 \\
(56.99)\end{array}$ & $\begin{array}{r}13.12 \\
(91.06)\end{array}$ & $\begin{array}{l}229.3^{*} \\
(116.3)\end{array}$ & $\begin{array}{r}-69.13 \\
(117.1)\end{array}$ & $\begin{array}{r}400.0 \\
(294.9)\end{array}$ & $\begin{array}{r}17.27 \\
(153.4)\end{array}$ \\
\hline \multicolumn{7}{|l|}{$p$ value on tests of joint significance } \\
\hline Either Treatment with Consulting & 0.28 & 0.90 & 0.11 & 0.57 & 0.19 & 0.89 \\
\hline $\begin{array}{l}\text { Either Treatment with Capital } \\
p \text { value on tests of equality of means }\end{array}$ & $0.09 *$ & 0.83 & $0.01 * *$ & 0.57 & 0.19 & 0.39 \\
\hline Either Treatment with Consulting & 0.43 & 0.56 & $0.03 * *$ & 0.82 & 0.55 & 0.66 \\
\hline Either Treatment with Capital & $0.08 *$ & 0.93 & 0.41 & 0.84 & 0.54 & $0.09 *$ \\
\hline Observations & 153 & 149 & 153 & 149 & 153 & 149 \\
\hline
\end{tabular}

${ }^{*} \mathrm{p}<.10,{ }^{* *} \mathrm{p}<.05,{ }^{* * *} \mathrm{p}<.01$

Robust standard errors in parentheses.

Controls for baseline value and stratification variables (neighborhood) in all regressions.

Columns 1 and 2 winsorized at the highest 1\%. Columns 3-5 winsorized at highest and lowest $1 \%$

See Appendix Table 3 for breakdown of likely investment categories at baseline.

Columns 3 and 4 are investment in goal category plus savings minus loans taken.

Columns 5 and 6 are total investment plus savings minus loans taken. 


\begin{tabular}{|c|c|c|c|c|c|c|c|c|}
\hline & $\begin{array}{c}\begin{array}{c}\text { Stated } \\
\text { Income }\end{array} \\
(1)\end{array}$ & $\frac{\text { Revenue }}{(2)}$ & $\frac{\text { Expenses }}{(3)}$ & $\begin{array}{c}\begin{array}{c}\text { Revenue } \\
\text { less } \\
\text { Expenses }\end{array} \\
(4)\end{array}$ & $\begin{array}{c}\begin{array}{c}\text { Hours } \\
\text { Worked } \\
\text { per Month }\end{array} \\
\frac{(5)}{(5)}\end{array}$ & $\begin{array}{c}\begin{array}{c}\text { Total } \\
\text { Staff }\end{array} \\
(6)\end{array}$ & $\frac{\text { Apprentices }}{(7)}$ & $\begin{array}{c}\begin{array}{c}\text { Paid } \\
\text { Employees }\end{array} \\
(8)\end{array}$ \\
\hline Consulting Only & $\begin{array}{r}0.905 \\
(21.42)\end{array}$ & $\begin{array}{r}-33.34 \\
(38.76)\end{array}$ & $\begin{array}{c}-18.24 \\
(29.97)\end{array}$ & $\begin{array}{r}-16.50 \\
(22.47)\end{array}$ & $\begin{array}{r}2.325 \\
(11.40)\end{array}$ & $\begin{array}{l}0.0565 \\
(0.205)\end{array}$ & $\begin{array}{l}0.0687 \\
(0.157)\end{array}$ & $\begin{array}{l}0.0474 \\
(0.106)\end{array}$ \\
\hline Capital Only & $\begin{array}{r}-45.43^{* *} \\
(21.99)\end{array}$ & $\begin{array}{r}29.24 \\
(86.31)\end{array}$ & $\begin{array}{r}12.52 \\
(49.82)\end{array}$ & $\begin{array}{r}-31.03 \\
(34.15)\end{array}$ & $\begin{array}{r}4.284 \\
(10.89)\end{array}$ & $\begin{array}{l}-0.158 \\
(0.205)\end{array}$ & $\begin{array}{l}0.0166 \\
(0.146)\end{array}$ & $\begin{array}{l}-0.169 \\
(0.112)\end{array}$ \\
\hline Consulting \& Capital & $\begin{array}{r}-23.23 \\
(20.06) \\
\end{array}$ & $\begin{array}{r}-29.94 \\
(39.43) \\
\end{array}$ & $\begin{array}{r}7.778 \\
(34.36) \\
\end{array}$ & $\begin{array}{r}-39.06 \\
(25.13) \\
\end{array}$ & $\begin{array}{r}-12.87 \\
(11.63) \\
\end{array}$ & $\begin{array}{r}-0.0159 \\
(0.192) \\
\end{array}$ & $\begin{array}{r}-0.0376 \\
(0.155) \\
\end{array}$ & $\begin{array}{r}0.104 \\
(0.117) \\
\end{array}$ \\
\hline \multicolumn{9}{|l|}{$p$ value on tests of joint significance } \\
\hline $\begin{array}{l}\text { Either treatment with Consulting } \\
\text { Either treatment with Capital } \\
p \text { value on tests of equality of means }\end{array}$ & $\begin{array}{l}0.52 \\
0.06\end{array}$ & $\begin{array}{l}0.34 \\
0.99\end{array}$ & $\begin{array}{l}0.85 \\
0.77\end{array}$ & $\begin{array}{l}0.15 \\
0.14\end{array}$ & $\begin{array}{l}0.58 \\
0.65\end{array}$ & $\begin{array}{l}0.91 \\
0.61\end{array}$ & $\begin{array}{l}0.91 \\
0.93\end{array}$ & $\begin{array}{l}0.44 \\
0.74\end{array}$ \\
\hline Either treatment with Consulting & 0.29 & 0.93 & 0.42 & 0.43 & 0.25 & 0.73 & 0.53 & 0.61 \\
\hline Either treatment with Capital & 0.30 & 0.49 & 0.92 & 0.83 & 0.17 & 0.49 & 0.74 & 0.02 \\
\hline Observations & 747 & 445 & 447 & 426 & 452 & 302 & 302 & 302 \\
\hline Rounds with Data & $1,3,5,6,7,8$ & $1,5,6,8$ & $1,5,6,8$ & $1,5,6,8$ & $1,3,6,8$ & $1,6,8$ & $1,6,8$ & $1,6,8$ \\
\hline Individuals & 154 & 154 & 154 & 154 & 154 & 153 & 153 & 153 \\
\hline Outcome Mean at Baseline & 111.9 & 235.0 & 244.9 & 1.2 & 243.0 & 1.3 & 0.9 & 0.4 \\
\hline
\end{tabular}

$* \mathrm{p}<.10, * * \mathrm{p}<.05, * * * \mathrm{p}<.01$

Robust standard errors clustered by individual in parentheses.

Controls for baseline value and stratification variables (neighborhood) in all regressions.

Revenue, expenses and revenue less expenses all include both baseline revenue and baseline expenses as controls for consistency.

Profit, Revenue less expenses and profit per hour are winsorized (capped) at highest and lowest 1\%.

Revenue, expenses and hours worked are winsorized (capped) at the highest $1 \%$.

Revenue less Expenses does not equal the Revenue coefficient minus the Expenses coefficient because of the unequal number of observations. 
Table 7: Profitability by Round

OLS

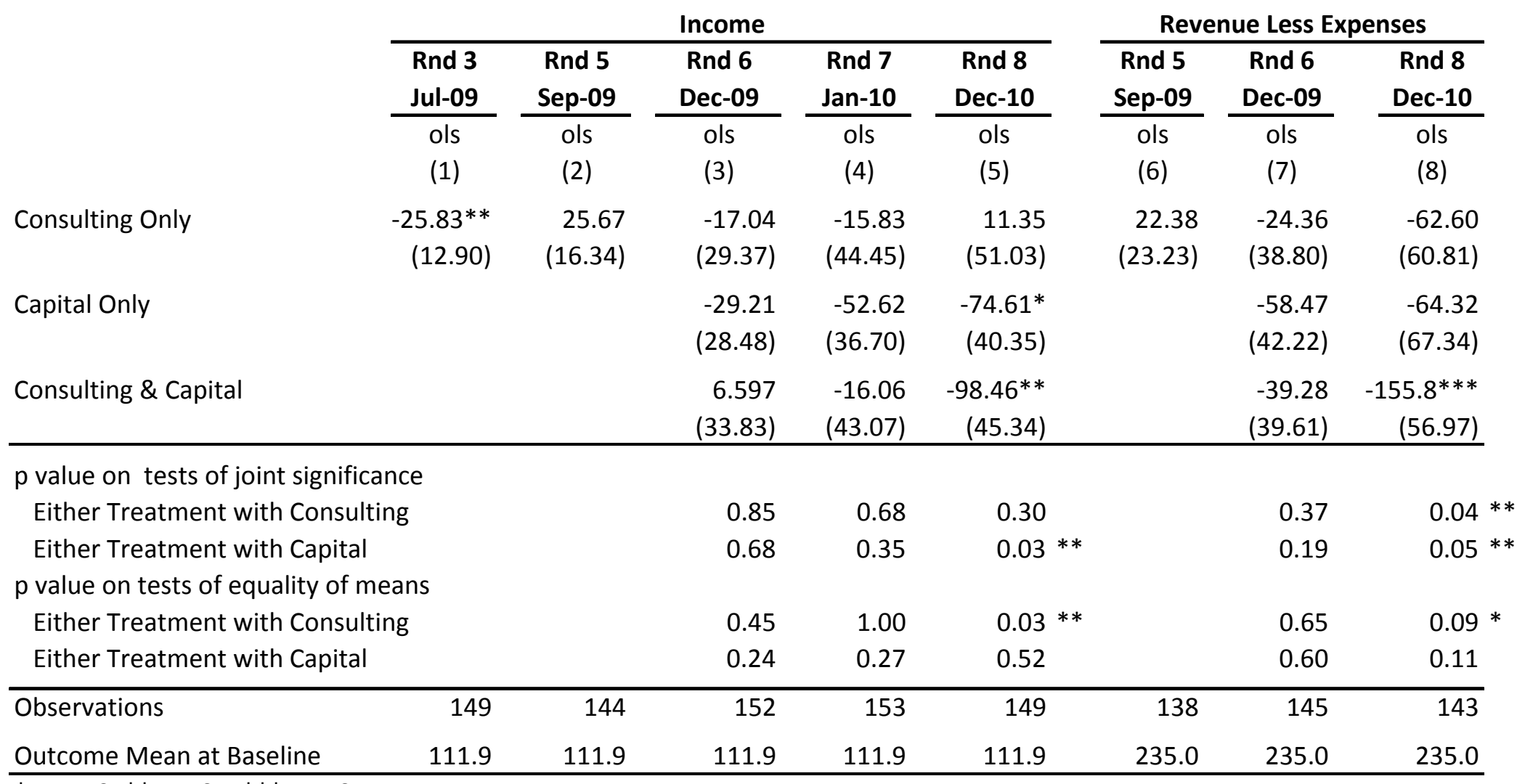

Revenue Less Expenses

${ }^{*} \mathrm{p}<.10,{ }^{* *} \mathrm{p}<.05, * * * \mathrm{p}<.01$

Robust standard errors in parentheses.

Controls for baseline value and stratification variables (neighborhood) in all regressions.

Consulting includes all 77 individuals assigned to the consulting group in rounds 3 and 5 .

Revenue and expenses include both baseline revenue and baseline expenses as controls for consistency.

Revenue and expenses are winsorized at the highest $1 \%$ and income is winsorized at the highest and lowest $1 \%$. 
Table 8: Daily Visits Results

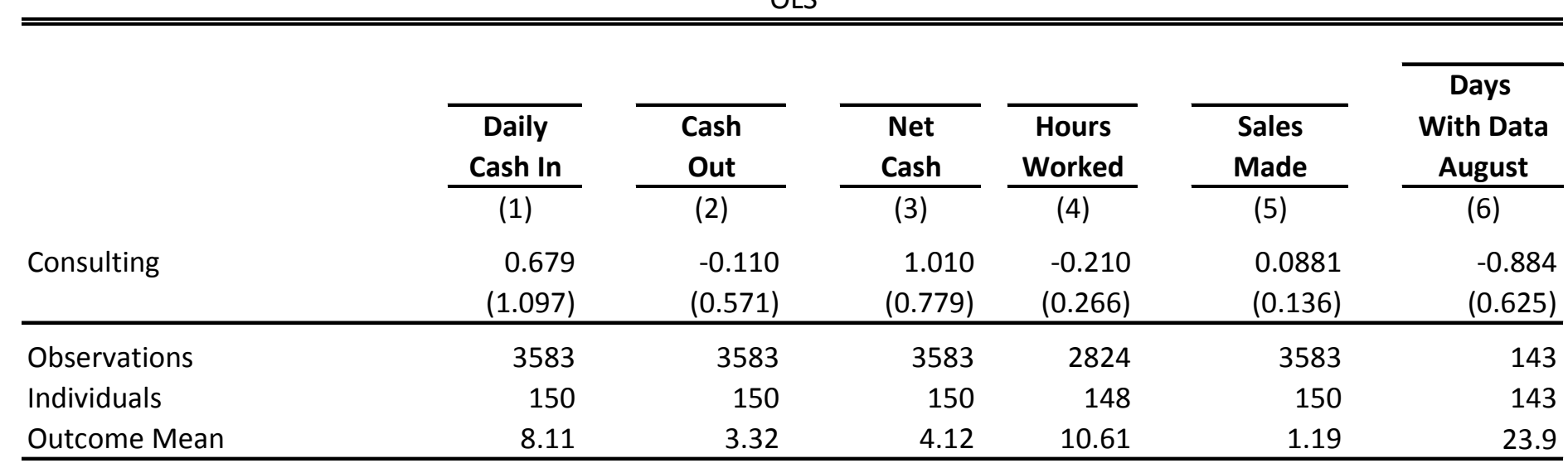

$* p<.10, * * p<.05, * * * p<.01$

Robust standard errors in parentheses, clustered by individual where more than one day is combined (columns 1-5).

Controls for baseline profit, stratification variables (neighborhood) and day.

Consulting includes all 77 individuals assigned to the consulting group.

All outcomes are winsorized at the highest $1 \%$. 


\section{Appendix Tables}

\section{Appendix Table 1: Baseline Characteristics}

Income Last Month

Average Monthly Revenue

Monthly Expenses Excluding Rent

Working Capital

Fair Value of Fixed Assets

Number of Paid Employees

Keeps Financial Records

Has Ever Taken a Loan

\begin{tabular}{|c|c|c|c|c|c|}
\hline Mean & SD & Min & Median & Max & $\mathrm{N}$ \\
\hline 114 & 123 & 0 & 80 & 1000 & 141 \\
\hline 240 & 225 & 12 & 200 & 2000 & 154 \\
\hline 237 & 261 & 3 & 151 & 1712 & 160 \\
\hline 184 & 264 & 0 & 100 & 2000 & 156 \\
\hline 1566 & 1976 & 110 & 1140 & 20230 & 160 \\
\hline 0.4 & 0.6 & 0.0 & 0.0 & 4.0 & 160 \\
\hline 0.2 & 0.4 & 0.0 & 0.0 & 1.0 & 160 \\
\hline 0.1 & 0.3 & 0.0 & 0.0 & 1.0 & 160 \\
\hline
\end{tabular}

\section{Appendix Table 2: Attrition}

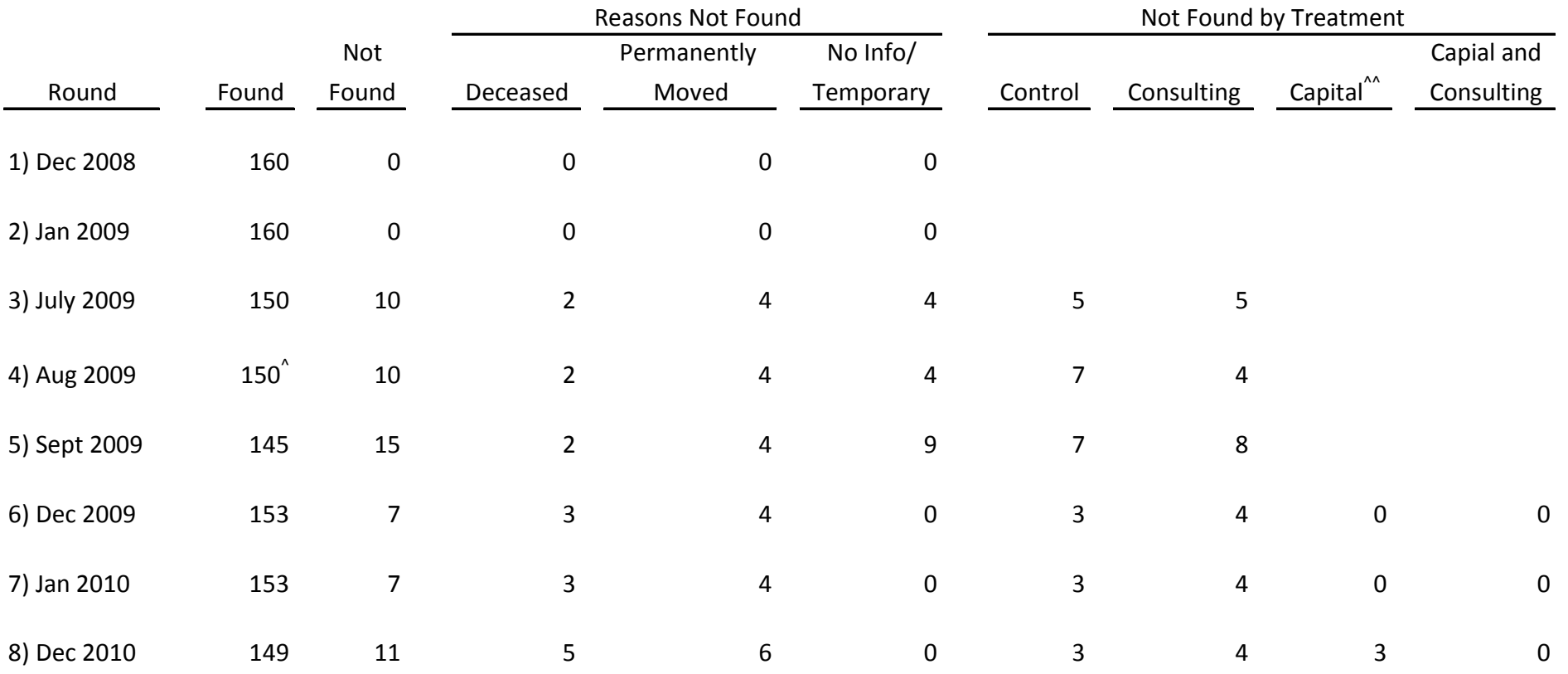

$\wedge$ Found on at least one day

$\wedge \wedge$ Note that capital group randomization excluded 6 individuals not found in any of rounds 3-5. 


\begin{tabular}{|c|c|c|}
\hline \multicolumn{3}{|c|}{ OLS } \\
\hline & $\begin{array}{l}\text { Hours of } \\
\text { Consulting }\end{array}$ & $\begin{array}{c}\% \text { of } \\
\text { Practices } \\
\text { Adopted }\end{array}$ \\
\hline & $(1)$ & $(2)$ \\
\hline \multirow[t]{2}{*}{ Male } & 0.447 & -0.0554 \\
\hline & $(1.031)$ & $(0.0513)$ \\
\hline \multirow[t]{2}{*}{ Baseline Income } & $0.00474 * *$ & 0.000139 \\
\hline & $(0.00235)$ & $(0.000196)$ \\
\hline \multirow[t]{2}{*}{ Consultant 2} & -1.834 & 0.0133 \\
\hline & $(1.485)$ & $(0.0693)$ \\
\hline \multirow[t]{2}{*}{ Consultant 3} & $-5.018 * * *$ & 0.0386 \\
\hline & $(1.682)$ & $(0.0836)$ \\
\hline \multirow[t]{2}{*}{ Consultant 4} & $-3.030 * *$ & 0.0677 \\
\hline & (1.338) & $(0.0798)$ \\
\hline \multirow[t]{2}{*}{ Size of Social Network } & $-0.421 * *$ & 0.00769 \\
\hline & $(0.206)$ & $(0.00889)$ \\
\hline \multirow[t]{2}{*}{ Business Place is Permanent Structure } & -0.0215 & 0.0382 \\
\hline & $(1.235)$ & $(0.0575)$ \\
\hline \multirow[t]{2}{*}{ Business is Registered } & -0.833 & -0.0295 \\
\hline & $(0.942)$ & $(0.0540)$ \\
\hline \multirow[t]{2}{*}{ Baseline Staff } & -0.0148 & 0.0280 \\
\hline & $(0.345)$ & $(0.0190)$ \\
\hline \multirow[t]{2}{*}{ Years of Education } & 0.0207 & 0.0202 \\
\hline & $(0.172)$ & $(0.0145)$ \\
\hline \multirow[t]{2}{*}{ Years of Experience as Tailor } & 0.328 & 0.00892 \\
\hline & $(0.551)$ & $(0.0263)$ \\
\hline \multirow[t]{2}{*}{ Log of Baseline Asset Replacement Cost } & 0.948 & -0.0267 \\
\hline & $(0.745)$ & $(0.0400)$ \\
\hline \multirow[t]{2}{*}{ Digits Backwards } & -0.0907 & -0.0346 \\
\hline & $(0.427)$ & (0.0308) \\
\hline \multirow[t]{2}{*}{ Member of a Tailors' Association } & 0.337 & 0.0221 \\
\hline & $(1.004)$ & $(0.0615)$ \\
\hline Observations & 76 & 76 \\
\hline Mean Value & 10.02 & 0.323 \\
\hline
\end{tabular}

${ }^{*} \mathrm{p}<.10,{ }^{* *} \mathrm{p}<.05, * * * \mathrm{p}<.01$

Robust standard errors in parentheses.

Consulting includes all individuals assigned to the consulting group, except 3 who passed away and one who is missing data.

All regressions include controls for stratification variables (neighborhood). 


\section{Appendix Table 4: Business Literacy and Practices Spillovers Specification of Table 2, with Spillovers}

OLS

\begin{tabular}{|c|c|c|c|c|c|}
\hline & \multicolumn{2}{|c|}{ Business Practices Index } & & \multicolumn{2}{|c|}{ Business Practices Inde) } \\
\hline & $\begin{array}{l}\text { Pooled } \\
\text { (1) }\end{array}$ & $\begin{array}{r}\text { Pooled } \\
\text { (2) }\end{array}$ & & $\begin{array}{l}\text { Pooled } \\
\text { (3) }\end{array}$ & $\begin{array}{l}\text { Pooled } \\
\text { (4) }\end{array}$ \\
\hline Consulting Only or Consulting \& Capital & $\begin{array}{l}0.0353 * \\
(0.0201)\end{array}$ & $\begin{array}{r}0.0278 \\
(0.0219)\end{array}$ & Consulting Only or Consulting \& Capital & $\begin{array}{l}0.0340 * \\
(0.0203)\end{array}$ & $\begin{array}{r}0.0556 \\
(0.0391)\end{array}$ \\
\hline (Minimum Distance to Consulting)*( Consulting) & & $\begin{array}{r}0.0336 \\
(0.0222) \\
\end{array}$ & (Number of Consulting Tailors in $0.5 \mathrm{~km}$ )*( Consulting) & & $\begin{array}{r}-0.00516 \\
(0.00730) \\
\end{array}$ \\
\hline Observations & 749 & 749 & Observations & 749 & 749 \\
\hline Rounds with Data & $1,2,3$, & $6,7,8$ & Rounds with Data & $3,5,6,7,8$ & \\
\hline Individuals & 154 & 154 & Individuals & 154 & 154 \\
\hline Outcome Mean at Baseline & 0.398 & 0.398 & Outcome Mean at Baseline & 0.398 & 0.398 \\
\hline Control for Outcome Value at Baseline & Yes & Yes & Control for Outcome Value at Baseline & Yes & Yes \\
\hline Number of items in practices index & 35 & 19 & Number of items in practices index & 35 & 19 \\
\hline
\end{tabular}

$* \mathrm{p}<.10 * * \mathrm{p}<.05, * * * \mathrm{p}<.01$

Standard errors in parentheses, clustered by individual where more than one round is combined (columns 2 and 6).

All regressions include controls for baseline value (except column 1, which has no baseline measurement) and stratification variables (neighborhood).

Business Practices is the percentage of all practices recommended by the consultants that were adopted in that round. All practices were not measured in all rounds. 


\section{Appendix Table 5: Stated Uses of Capital}

\begin{tabular}{|c|c|c|c|c|}
\hline \multirow{2}{*}{$\begin{array}{l}\text { Hypothetical } \\
\text { Likely Use for } \\
200 \text { Cedi Grant } \\
\text { (at baseline) }\end{array}$} & \multicolumn{4}{|c|}{$\begin{array}{c}\text { Actual Use for } 200 \text { Cedi Grant } \\
\text { (self reported after capital drop) }\end{array}$} \\
\hline & Machines & Property & Inputs & Other \\
\hline \multicolumn{5}{|l|}{ Consulting \& Capital } \\
\hline Machines & 0 & 0 & 1 & 3 \\
\hline Property & 0 & 2 & 2 & 0 \\
\hline Inputs & 7 & 1 & 9 & 12 \\
\hline Other & 0 & 0 & 0 & 0 \\
\hline Total Consult \& Capital & 7 & 3 & 12 & 15 \\
\hline \multicolumn{5}{|l|}{ Capital Only } \\
\hline Machines & 2 & 2 & 1 & 0 \\
\hline Property & 0 & 1 & 1 & 1 \\
\hline Inputs & 5 & 4 & 17 & 7 \\
\hline Other & 0 & 0 & 0 & 0 \\
\hline Total Capital Only & 7 & 7 & 19 & 8 \\
\hline \multicolumn{5}{|l|}{ Overall } \\
\hline Machines & 2 & 2 & 2 & 3 \\
\hline Property & 0 & 3 & 3 & 1 \\
\hline Inputs & 12 & 5 & 26 & 19 \\
\hline Other & 0 & 0 & 0 & 0 \\
\hline Overall Total & 14 & 10 & 31 & 23 \\
\hline
\end{tabular}

Note: Some people split the money into different categories, so reported uses are greater than the number baseline likely uses.

One person is missing actual use data.

Other uses includes saving, domestic use and paying down debt

Chi2 that distribution of Consulting \& Capital uses $=$ Capital Only uses $=7.5, p=.19$ 


\section{Appendix Table 6: Profitability Pooled (Table 6), with Gender Interactions}

OLS

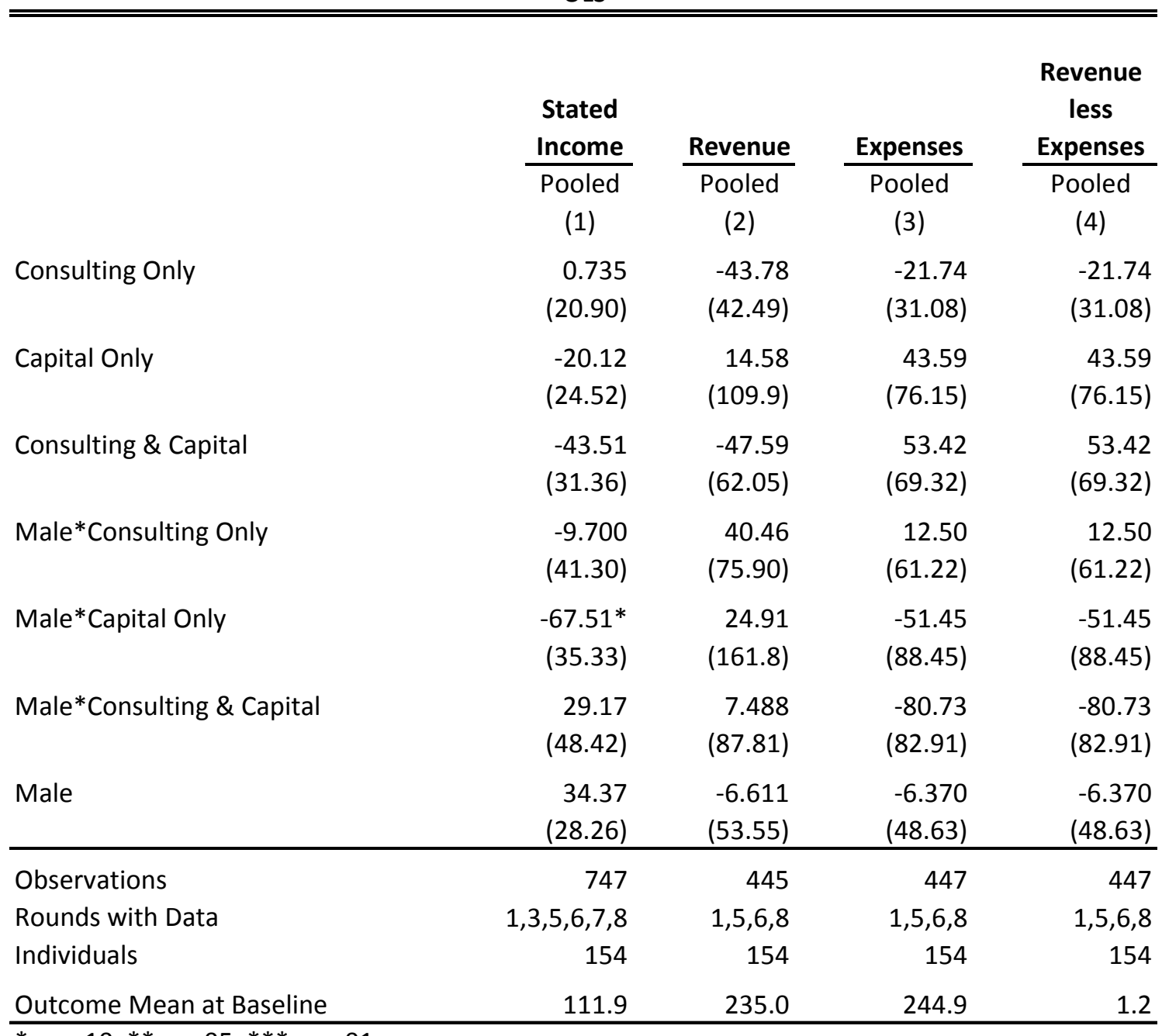

${ }^{*} \mathrm{p}<.10, * * \mathrm{p}<.05, * * * \mathrm{p}<.01$

Robust standard errors in parentheses, clustered by individual where more than one day is combined (columns 1-5).

Controls for baseline profit, stratification variables (neighborhood) and day.

Revenue, expenses and revenue less expenses all include both baseline revenue and baseline expenses as controls for consistency.

Profit, Revenue less expenses and profit per hour are winsorized (capped) at highest and lowest $1 \%$.

Revenue, expenses and hours worked are winsorized (capped) at the highest $1 \%$. 
Appendix Table 7: Profitability Pooled (Table 6), with Tailor Fixed Effects

Fixed Effects

\begin{tabular}{|c|c|c|c|c|c|c|c|c|}
\hline & $\begin{array}{c}\text { Stated } \\
\text { Income }\end{array}$ & $\frac{\text { Revenue }}{(2)}$ & $\frac{\text { Expenses }}{(3)}$ & $\begin{array}{c}\begin{array}{c}\text { Revenue } \\
\text { less } \\
\text { Expenses }\end{array} \\
(4)\end{array}$ & $\begin{array}{c}\begin{array}{c}\text { Hours } \\
\text { Worked } \\
\text { per Month }\end{array} \\
\frac{(5)}{}\end{array}$ & $\begin{array}{c}\text { Total } \\
\text { Staff }\end{array}$ & $\frac{\text { Apprentices }}{(7)}$ & $\begin{array}{c}\begin{array}{c}\text { Paid } \\
\text { Employees }\end{array} \\
(8)\end{array}$ \\
\hline Consulting Only & $\begin{array}{r}-16.15 \\
(27.04)\end{array}$ & $\begin{array}{l}-69.88 \\
(46.12)\end{array}$ & $\begin{array}{r}29.37 \\
(43.48)\end{array}$ & $\begin{array}{r}-103.6^{* *} \\
(51.73)\end{array}$ & $\begin{array}{r}6.131 \\
(14.47)\end{array}$ & $\begin{array}{l}-0.154 \\
(0.232)\end{array}$ & $\begin{array}{l}-0.137 \\
(0.183)\end{array}$ & $\begin{array}{l}0.0623 \\
(0.113)\end{array}$ \\
\hline Capital Only & $\begin{array}{r}-42.54^{* *} \\
(19.00)\end{array}$ & $\begin{array}{r}40.24 \\
(73.63)\end{array}$ & $\begin{array}{r}7.059 \\
(48.88)\end{array}$ & $\begin{array}{r}-11.76 \\
(38.55)\end{array}$ & $\begin{array}{r}-2.533 \\
(12.50)\end{array}$ & $\begin{array}{l}-0.196 \\
(0.235)\end{array}$ & $\begin{array}{l}0.0201 \\
(0.174)\end{array}$ & $\begin{array}{c}-0.221 * \\
(0.131)\end{array}$ \\
\hline Consulting \& Capital & $\begin{array}{r}-24.97 \\
(28.69) \\
\end{array}$ & $\begin{array}{r}-29.66 \\
(45.13) \\
\end{array}$ & $\begin{array}{r}32.91 \\
(55.85) \\
\end{array}$ & $\begin{array}{l}-87.66^{*} \\
(50.41) \\
\end{array}$ & $\begin{array}{r}-11.61 \\
(11.73) \\
\end{array}$ & $\begin{array}{r}-0.0471 \\
(0.213) \\
\end{array}$ & $\begin{array}{r}-0.0984 \\
(0.184) \\
\end{array}$ & $\begin{array}{r}0.153 \\
(0.127) \\
\end{array}$ \\
\hline \multicolumn{9}{|l|}{$p$ value on tests of joint significance } \\
\hline $\begin{array}{l}\text { Any Consulting } \\
\text { Any Capital } \\
p \text { value on tests of equality of means }\end{array}$ & $\begin{array}{l}0.35 \\
0.07 *\end{array}$ & $\begin{array}{l}0.20 \\
0.90\end{array}$ & $\begin{array}{l}0.47 \\
0.62\end{array}$ & $\begin{array}{l}0.04^{* *} \\
0.18\end{array}$ & $\begin{array}{l}0.80 \\
0.49\end{array}$ & $\begin{array}{l}0.60 \\
0.53\end{array}$ & $\begin{array}{l}0.45 \\
0.80\end{array}$ & $\begin{array}{l}0.29 \\
0.75\end{array}$ \\
\hline Consulting \& Capital = Consulting & 0.80 & 0.41 & 0.95 & 0.74 & 0.25 & 0.65 & 0.84 & 0.49 \\
\hline Consulting \& Capital = Capital & 0.57 & 0.41 & 0.70 & 0.14 & 0.50 & 0.53 & 0.52 & 0.01 \\
\hline Observations & 799 & 580 & 607 & 580 & 612 & 462 & 462 & 462 \\
\hline Rounds with Data & $1,3,5,6,7,8$ & $1,5,6,8$ & $1,5,6,8$ & $1,5,6,8$ & $1,3,6,8$ & $1,6,8$ & $1,6,8$ & $1,6,8$ \\
\hline Individuals & 141 & 154 & 160 & 154 & 154 & 160 & 160 & 160 \\
\hline Outcome Mean at Baseline & 111.9 & 235.0 & 244.9 & 1.2 & 243.0 & 1.3 & 0.9 & 0.4 \\
\hline
\end{tabular}

${ }^{*} \mathrm{p}<.10,{ }^{* *} \mathrm{p}<.05,{ }^{* * *} \mathrm{p}<.01$

Robust standard errors in parentheses.

Profit, Revenue less expenses and profit per hour are winsorized (capped) at highest and lowest $1 \%$.

Revenue, expenses and hours worked are winsorized (capped) at the highest $1 \%$. 


\section{Appendix Table 8: Comparison of Daily Visits Totals to Recall Data}

\begin{tabular}{|c|c|c|c|c|c|c|}
\hline \multicolumn{7}{|c|}{ OLS } \\
\hline & & & Daily Visits & Recall & $\begin{array}{c}\text { Difference } \\
\text { Daily - Recall }\end{array}$ & $\begin{array}{c}\text { Squared } \\
\text { Difference }\end{array}$ \\
\hline & & & $(1)$ & $(2)$ & $(3)$ & $(4)$ \\
\hline \multirow[t]{4}{*}{ Revenue } & (1) & Consulting & -1.248 & 24.25 & -4.081 & $22895.1 * *$ \\
\hline & & SE & $(37.37)$ & (26.34) & $(28.30)$ & (9362.6) \\
\hline & & $\mathrm{N}$ & 143 & 144 & 124 & 124 \\
\hline & & Mean & 207 & 223 & -12.6 & 24626 \\
\hline \multirow[t]{4}{*}{ Expenses } & (2) & Consulting & -27.39 & 5.541 & 8.712 & $9032.5^{* *}$ \\
\hline & & SE & $(37.52)$ & (13.17) & $(15.32)$ & (3882.5) \\
\hline & & $\mathrm{N}$ & 143 & 145 & 122 & 122 \\
\hline & & Mean & 99 & 110 & -15 & 8422 \\
\hline \multirow[t]{4}{*}{ Revenue less Expenses } & (3) & Consulting & 26.14 & 22.38 & -2.402 & 7626.5 \\
\hline & & SE & $(21.70)$ & $(23.23)$ & $(28.64)$ & $(10928.0)$ \\
\hline & & $\mathrm{N}$ & 143 & 138 & 126 & 126 \\
\hline & & Mean & 108 & 115 & 5.5 & 27197 \\
\hline
\end{tabular}

$* \mathrm{p}<.10, * * \mathrm{p}<.05, * * * \mathrm{p}<.01$

Robust standard errors in parentheses.

Controls for baseline revenue, baseline profit and stratification variables (neighborhood) in every regression.

Consulting includes all 80 individuals assigned to the consulting group.

Difference and squared difference regressions include only individuals found at least 20 times in the daily visits.

All outcomes are winsorized at the highest $1 \%$. 
Appendix Table 9: Comparable Study Result Weighting

\begin{tabular}{|c|c|c|c|c|c|c|c|c|}
\hline \multicolumn{9}{|c|}{ "Business Training Studies } \\
\hline \multirow[b]{2}{*}{ Study } & \multirow{2}{*}{\multicolumn{2}{|c|}{ Group }} & \multirow{2}{*}{$\begin{array}{c}\text { Profit } \\
\% \text { Change }\end{array}$} & \multirow{2}{*}{$\begin{array}{c}\text { Confidence } \\
\text { Interval }\end{array}$} & \multicolumn{3}{|c|}{ Sample Size } & \multirow[b]{2}{*}{ Weight } \\
\hline & & & & & Treatment & Control & Total & \\
\hline \multirow[t]{2}{*}{ Berge et al. (2012) [a] } & Male & & $5.4 \%$ & $(-20 \%,+38 \%)$ & 59.5 & 58 & 118 & 0.036 \\
\hline & Female & & $-3 \%$ & $(-23 \%,+22 \%)$ & 59.5 & 58 & 118 & 0.036 \\
\hline Bruhn and Zia (2012) & All & & $-15 \%$ & $(-62 \%,+32 \%)$ & 297 & 148 & 445 & 0.136 \\
\hline Calderon et al. (2012) & Female & & $24 \%$ & $(-1 \%, 56 \%)$ & 164 & 711 & 875 & 0.267 \\
\hline \multirow[t]{2}{*}{ De Mel et al. (2012) [b] } & Current Enterprises & & $-5.4 \%$ & $(-44 \%,+33 \%)$ & 200 & 114 & 314 & 0.096 \\
\hline & Potential Enterprises & & $43 \%$ & $(+6 \%,+80 \%)$ & 200 & 114 & 314 & 0.096 \\
\hline \multirow[t]{2}{*}{ Giné and Mansuri( 2011) [c] } & Mixed & & $-11 \%$ & $(-33 \%,+17 \%)$ & 186.5 & 187 & 374 & 0.114 \\
\hline & Male & & $-4.30 \%$ & $(-34 \%,+38 \%)$ & 186.5 & 187 & 374 & 0.114 \\
\hline Karlan and Valdivia (2011) & Mostly Female & & $17 \%$ & $(-25 \%,+59 \%)$ & 138 & 101 & 239 & 0.073 \\
\hline Mano et al. (2012) & Male & & $54 \%$ & $(+47 \%,+82 \%)$ & 47 & 66 & 113 & 0.034 \\
\hline Simple Average & \multicolumn{2}{|l|}{$10.5 \%$} & & & & & & \\
\hline Weighted Average & \multicolumn{2}{|l|}{$9.5 \%$} & & & & & & \\
\hline \multicolumn{9}{|c|}{ Capital Grant Studies } \\
\hline \multirow[b]{2}{*}{ Study } & \multirow{3}{*}{\multicolumn{2}{|c|}{ Group }} & Profit & Confidence & \multicolumn{3}{|c|}{ Sample Size } & \\
\hline & & & $\%$ Change & Interval & Treatment & Control & Total & Weight \\
\hline \multirow[t]{2}{*}{ del Mel et al. (2008) [d] } & & & $20 \%$ & $(-12 \%,+53 \%)$ & 84 & 81.5 & 166 & 0.117 \\
\hline & US\$200 Cash & & $36.9 \%$ & $(+12 \%,+62 \%)$ & 40 & 81.5 & 122 & 0.086 \\
\hline Fafchamps et al. (2012) [e] & US\$120 Cash & & $9.7 \%$ & $(-4.8,+24.2)$ & 198 & 396 & 594 & 0.419 \\
\hline Blattman et al. (2013) [f] & US\$382 to Potential Entrepreneurs & & $41.0 \%$ & $(+29 \%,+53 \%)$ & 265 & 270 & 535 & 0.378 \\
\hline Simple Average & & $26.9 \%$ & & & & & & \\
\hline Weighted Average & & $25.1 \%$ & & & & & & \\
\hline
\end{tabular}

[a] Sample size is based on 119 treatment groups and 116 control groups, split equallly for weighting purposes.

[b] Control sample size based on an even split of the total control size of 228 individuals.

[c] Sample isze is based on 373 treatment groups and 374 control groups, split equally for weighting purposes.

[d] Control size is based on a total control size of 163 individuals, split equally for weighting purposes.

[e] Profit change is based an absolute impact of 9.59 over a baseline mean of 99 .

[f] Sample size is groups.

Notes: Business training table based on tables 5 and 9 of McKenzie and Woodruff (2013).

We do not include Berge et al. (2012) in the capital grant studies because $100 \%$ of their sample were current clients of a microfinance instution, which presumably aliaviated their credit constraints, at least in part. Berge et al. (2012) found returns to capital of approximately $0 \%$. 